\title{
有機溶媒浸漬によるPMMAの粘弾性的性質の変化
}

九州歯科大学大学院歯学研究科㐘科理工学専攻 (指導 林 一郎教授)

矢鳴 律 生

\section{Changes of Viscoelastic Properties of Polymethyl Methacrylate Soaked in Various Organic Solvents}

By

\section{Ritsuo Yanaru}

Department of Dental Physicotechnology (Direct. : Prof. Ichiro Hayashi) Kyushu Dental College, Kitakyushu, Japan

The viscoelastic properties of polymethyl methacrylate have already been studied in detail and made clear by A. V. Tobolsky, A. E. Woodward, J. D. Ferry and others. They studied only its behavior in the atmospheric surroundings while in dental usages it is used selectively in oral cavity. The mechanical behavior in the air is surmised to be considerably different from that in saliva. To make clear such difference, the author measured the stress relaxation of specimens soaked in water as well as various organic solvents and examined their influence. The results obtained are as follows:

1) In course of dissolving of polymethyl methacrylate in organic solvents there can be found two different types of behavior, i. e. swelling and cracking, according to the solvents used.

2) The stress relaxation modulus of the soaked in acetone, benzene, xylene, eugenol is lower in the room temperature range than that of the unsoaked, while the glass transition temperature is not apparently changed by soaking.

3) The glass transition temperature of the specimen soaked in chloroform, which belongs to the swelling type, is lower than that of the unsoaked.

4) The specimen soaked in ethyl alcohol, which belongs to the swelling type, has more of temporary, physical cross-links provided by molecular chain entanglements than that of the unsoaked.

5) The stress relaxation behavior of the specimen soaked in water $\left(37^{\circ} \mathrm{C}\right)$ is similar to that of the unsoaked.

6) The specimen prepared directly by polymerization of pure monomer (MM specimen) and the specimen prepared by the dental method starting from monomer liquid and polymer powder (MP specimen) can not be relaxed so easily as the specimen prepared by heat pressing of polymer powder (PP specimen).

\footnotetext{
I 緒 言

1937年，ポリメタクリル酸メチル (PMMA) が義 䨑 床用材料として初めて歯科材料汇取り入れられて以来,
}

PMMAの需要度は急激に高 まり現在では義 歯の作製, 欠損歯の補綴，充填などに用いられている.

PMMA の物性に関する研究はすでに Tobolsky1),

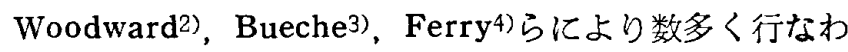


れ，その粘弾性的挙動もほほ明確になっている，しかし そのほとんどが空気中での挙動について論じたすので， 重合レジンの口腔内での挙動や有機溶媒による影響につ いて論じたあのは Tylman, Peyton, 林, 井上ら5〜10)によ ってなされているに過ぎない，そこで著者は応力縓和测 定により，調製法を異にする3 種の試料について，水お よび数種の有機溶媒に一定時間浸漬した場合の挙動と無 浸漬の場合の挙動之を比較検討し分子レベルでの考察を 加えた。

\section{II 実䀦装置}

この奏験に使用した装置11 12)(Fig. 1)は当教室で作製 したあのである.その原理図はFig. 2 に示す．まずフ

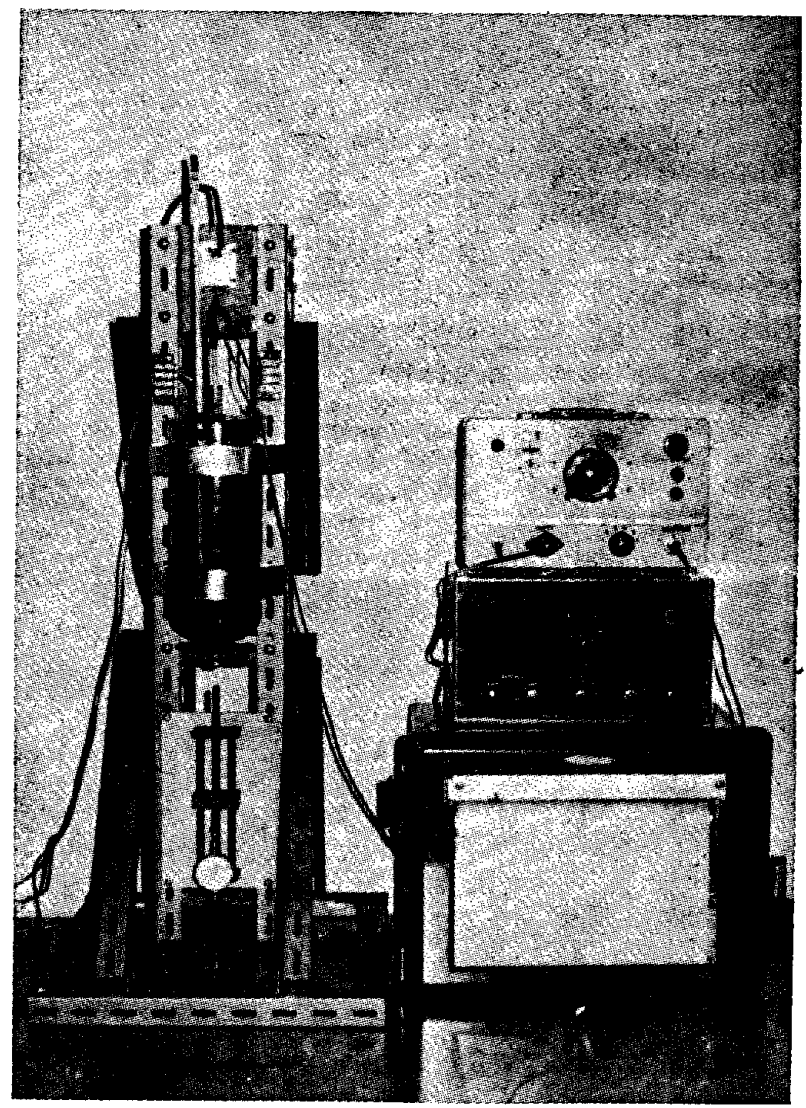

Fig. I Stress Relaxation Apparatus

イルム状試験片をチャック(C)間にはさみ, 微動駆動部(A) を回して試料に一定の単純引張りひずみを与える。試験 片に生ずる応力は测定器上部の非接着型ストレインゲー

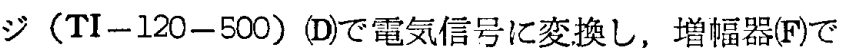
増幅した後，電子管式自動記録装置(G)で記録する，試験 片に与えた引張りひずみは，ダィヤルゲージ(B)で $\frac{1}{1000}$ $\mathrm{mm}$ まで読み取ることかできる，測定に使用した機器

(D， F， G）はいずれあ東洋ボールドウィン KK製であ る。高分子材料は温度依存性が大きいため，陚験片の周 辺はできるだけ温度变化がないようにしなければならな

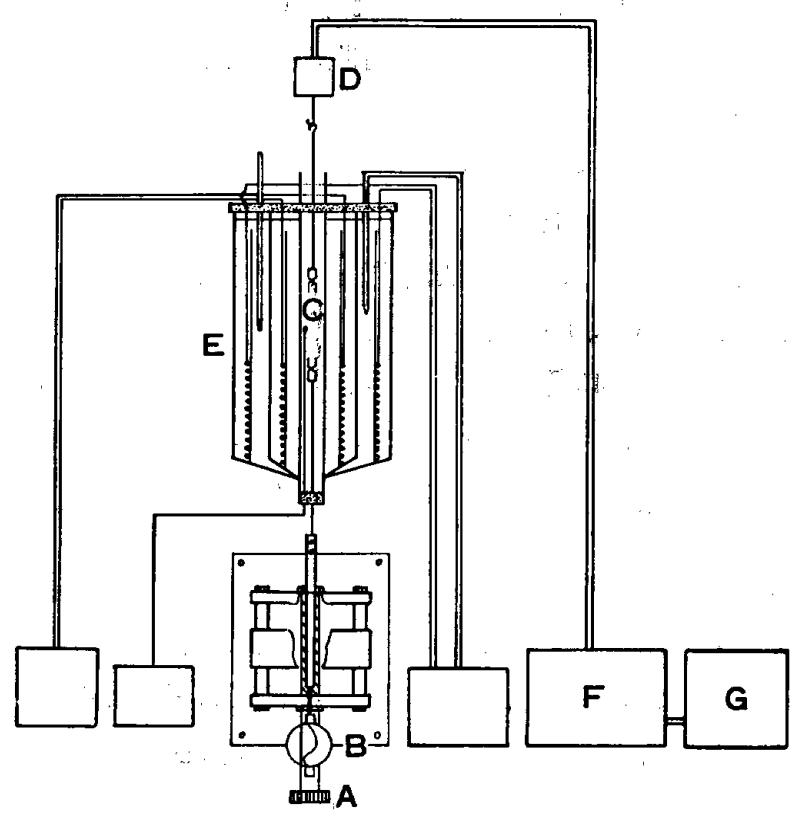

Fig. 2 Schematic Diagram showing the Principle of Stress Relaxation Apparatus

い.そのため，测定はガラス製のシリコーンオイルバス (E)中で行ない, 試験片周辺の温度变化は常に士0.1 $1^{\circ} \mathrm{C}$ 以 内になるように制御した。

\section{III 応力緩和つ理論的考察}

a 緩和弾性率 $\operatorname{Er}(\mathrm{t})^{13 \sim 15)}$

緩和弾性率は Hookeの法則より次式で与えられる。

$$
\operatorname{Er}(t)=\frac{f(t)}{\gamma}
$$

ただし $f(t)$ は応力， $\gamma$ は試料のひずみである。

b 温度一時間の重放合わせ原理の適用16 17)

20〜25種類の温度で得られた実測緩和弾性率

$\operatorname{Er}(t)$ 一時間 $(t)$ 曲線を時間の対数軸にそって移動し， 任意の基準温度での $\operatorname{Er}(\mathrm{t})$ - $\mathrm{t}$ 曲線に重ね, 一本の合成 曲線にする前に、緩和弾性率の值を密度と温度について 補正しなければならない，基準温度を $\mathrm{T}_{\mathrm{o}}\left({ }^{\circ} \mathrm{K}\right)$ とすると

$$
\operatorname{Er}(t)_{\text {red }}=\frac{T_{o} d_{o}}{T d} \operatorname{Er}(t)
$$

ただし $\operatorname{Er}(\mathrm{t})_{\text {red }}$ は換算緩和弾性率， $\mathrm{d}_{0}$ は基準温度 $\mathrm{T}_{\mathrm{o}}$ での試料の密度, $\mathrm{d}$ は温度 $\mathrm{T}\left({ }^{\circ} \mathrm{K}\right)$ での試料の密度, $\operatorname{Er}(\mathrm{t})$ は㬰測緩和弾性率である。

（2）式はゴム弾性理諭から導かれたあのであるが, 試 料の密度変化が小さいため密度の影響は無視できる。し たがって (2) 式は次のように書き換えられる.

$$
\operatorname{Er}(\mathrm{t})_{\mathrm{red}}=\frac{T_{\mathrm{o}}}{\mathrm{T}} \operatorname{Er}(\mathrm{t})
$$

各温度で得られた $\operatorname{Er}(t)-t$ 曲線を(3)式を用いて 


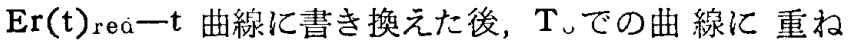
合わせる，乙の際の各曲線を時間の対数軸にそって移動 させる量は次式で与えられる。

$$
\log \mathrm{t}-\log \mathrm{t}_{\mathrm{o}}=\log a_{\mathrm{T}}
$$

ただし $a_{\mathrm{T}}$ は移動係数である.

粘弾性理論によれば，基準温度としてその試料のガラ 又転移温度（Tg）を選んで重称合わせを行なう場 合， $\mathrm{Tg}$ 以上では移動係数の対数 $\log a_{\mathrm{T}}$ と $(\mathrm{T}-\mathrm{Tg})\left({ }^{\circ} \mathrm{K}\right)$ の関係は次式 (WLF式)で示される。

$$
\log a_{\mathrm{T}}=\frac{-17.44(\mathrm{~T}-\mathrm{Tg})}{(51.6+\mathrm{T}-\mathrm{Tg})}
$$

C 㩊和過程における見かけの活性化エネルギー21 22) WLF 式が成立つ場合，緩和過程䎲扔ける見加けの活 性化エネルギー $(\Delta \mathrm{H})$ は次式で与えられる.

$$
\Delta \mathrm{H}=2.303 \mathrm{R}\left\{\frac{\mathrm{d}\left(\log a_{\mathrm{T}}\right)}{\mathrm{d}\left(\frac{\mathrm{l}}{\mathrm{T}}\right)}\right\}
$$

ただし， $\mathrm{R}$ は気体定数， $\mathrm{T}$ は温度 $\left({ }^{\circ} \mathrm{K}\right) ， a_{\mathrm{r}}$ は移動係数 である。

（5）式を（6）式に代入すると（6）式は次式のように書 き換えられる。

$$
\Delta \mathrm{H}=\frac{4.12 \times 10^{3} \mathrm{~T}^{2}}{(51.6+\mathrm{T}-\mathrm{Tg})^{2}}
$$

$\mathrm{d}$ 緩和スペクトル（第1次近似法）

緩和時間の分布は次式23 25)で定義される.

$$
\operatorname{Er}(t)=\int_{0}^{\infty} \operatorname{Er}(t) \exp (-\tau / t) d \tau
$$

ただし $\operatorname{Er}(t)$ は緩和弾性率, $\operatorname{Er}(\tau)$ は緩和スペクトル である。緩和弾性率は $\log \operatorname{Er}(\mathrm{t})-\log \mathrm{t}$ 曲線として表 わしたため，

（8）式を対数目盛にした場合について考える.

$$
\operatorname{Er}(\tau)=\frac{H(\ln \tau)}{\tau}
$$

とし, 微予形で表わすと

$$
\mathrm{H}(\ln \tau) \mathrm{d}(\ln \tau)=\operatorname{Er}(\tau) \mathrm{d} \tau
$$

となるから，(8) 式は次式のように書き換えられる.

$$
\begin{aligned}
& \operatorname{Er}(t)=\int_{0}^{\infty} H(\ln \tau) \exp \left(-\frac{t}{\tau}\right) d(\ln \tau)(10) \\
& \left.\begin{array}{rl}
\mathbf{0}<\mathbf{t} \leq \tau \text { のとき } & \exp \left(-\frac{\mathrm{t}}{\tau}\right)=1 \\
\mathbf{t}>\tau \text { のとき } & \exp \left(-\frac{\mathrm{t}}{\tau}\right)=0
\end{array}\right\}
\end{aligned}
$$

となる第一次近似法では(10)式は

$$
\mathrm{H}(\ln \tau)=-\left[\frac{\mathrm{d}\{\operatorname{Er}(\mathrm{t})\}}{\mathrm{d}(\ln \tau)}\right]_{\mathrm{t}=\tau}
$$

のようになる.
次に緩和弾性率 $\operatorname{Er}(\mathbf{t})$ む対数目盛で表わすとすれば （11）式は次式のようになる。

$$
\mathrm{H}(\ln \tau)=-\left[\operatorname{Er}(\mathrm{t}) \frac{\mathrm{d}\{\ln \operatorname{Er}(\mathrm{t})\}}{\mathrm{d}(\ln \mathrm{t})}\right]_{\mathrm{t}=\tau^{(12)}}
$$

\section{N 実験材料と試鏂片の作製}

\section{1 実験材料}

本実験に使用した材料は，試薬１級のメタクリル酸メ チルならびに義㐘床用レジンとほぼ同じ平均粒度（67 クロン）上粘度平均分子量（30厅）を有し，顔料その他 を含まない一次製品の透明なパール状ポリメタクリル酸 メチルである26〜28).

\section{2 測定試料}

測定に供した試料㳄の 3 種類である。

（1）パール状ポリマーのみを表面を滑らかに研磨 した 2 枚の真鍮板の間に 錫簿を介してはさみ， $180^{\circ} \mathrm{C}$ 亿10分間加熱しながら加圧融着しフィルム 状としたもの，以後この試料をPPと略記する。

(2) ポリマー対モノマーの重量比を2:1上し，モ ノマー重量の0.5\%の過酸化ベンゾイルを加え(1) の場合と同じプレスを用いて歯科の通法に準じた 乾熱法で加熱重合しフィルム状にしたあの. 重合 は常温より $100^{\circ} \mathrm{C}$ まで30分で加熱し， $100^{\circ} \mathrm{C}$ に6 分保持して完結させた。 以後ての武料を MP 上略 氾する。

（3）モノマーに重是比で $0.5 \%$ 過酸化ベンゾイ ルを加えたものを $60^{\circ} \mathrm{C}$ に 5 時問保持してシロッ プ状にした後，(2) と同じ 条件でフィルム状に

重合した。 以後この試料を $M M$ 之略記する。

いずれの場合もフィルムの厚さは $0.25 \sim 0.30 \mathrm{~mm}$ に なるように材料の分量および压力を調節した。 これらの フィルムから幅 1. 10〜 1. $20 \mathrm{~mm}$ ，長さ55mm大の薄板を 切り取り試験片とした。各試験片にはフィルム作製過程 で生じた内部応力が残存していると思われるので，窒素 雾囲気中で $75 \sim 100^{\circ} \mathrm{C}$ 亿 6 時開熬留後徐冷上いう処理に よりこれを除去した。

\section{V 実験方法}

各試験片を数種類の有機溶媒抢よび水に，それぞれに 応じた時間浸漬の後, 恒量になるまで真空乾燥して各種 の試料を作製した。

本実験に用いた有機溶媒は acetone, benzene, xylene, chloroform, eugenol, ethyl alcohol の 6 種 類である，各溶媒に応じた浸漬時間を決定するために 
Table 1 Soaked Time in various Solvents

\begin{tabular}{|l|r|r|r|}
\hline \multicolumn{1}{|c|}{ Solvent } & P P & \multicolumn{1}{c|}{ M P } & M M \\
\hline Acetone & I (M) & $2(\mathbf{M})$ & $3(\mathbf{M})$ \\
Benzene & $15(\mathbf{M})$ & $15(\mathbf{M})$ & $10(\mathbf{M})$ \\
Xylene & $30(\mathbf{M})$ & $60(\mathbf{M})$ & $60(\mathbf{M})$ \\
Chloroform & $1(\mathbf{M})$ & $2(\mathbf{M})$ & $1(\mathbf{M})$ \\
Eugenol & $1.5(\mathbf{H})$ & $3(\mathrm{H})$ & $3(\mathrm{H})$ \\
Ethyl alcohol & $6(\mathrm{H})$ & $6(\mathrm{H})$ & $48(\mathrm{H})$ \\
Water & $3(\mathrm{~W})$ & $3(\mathrm{~W})$ & $3(\mathrm{~W})$ \\
\hline
\end{tabular}

予備実験を行ない，溶媒効果が現われ，しかも試験片の 表面にクラックあるいは欠損部を生じない限度内に打け る最大時間を目安とした，各試料の浸漬時閶は Table I に示す。

浸漬した溶媒名の頭文字をとって acetone では A, benzene では B, xylene ではX, chloroformでは C, eugenol では Eu, ethyl alcohol ではEt, 水ではWを $\mathrm{PP}, \mathrm{MP}, \mathrm{MM}$ なる記号の後に付記して, 試料の区別を 明らかにした。なお無浸漬試料の場合はOを付記した。

\section{V 実験結果}

溶媒無浸漬試料PP-O, MP - O , MM-O の綬和弾性 率の温度依存性をFig. 3〜 5 亿図示した。各值は Table 2〜4に示す.これによるとPP-Oが最す緩和しやすく，

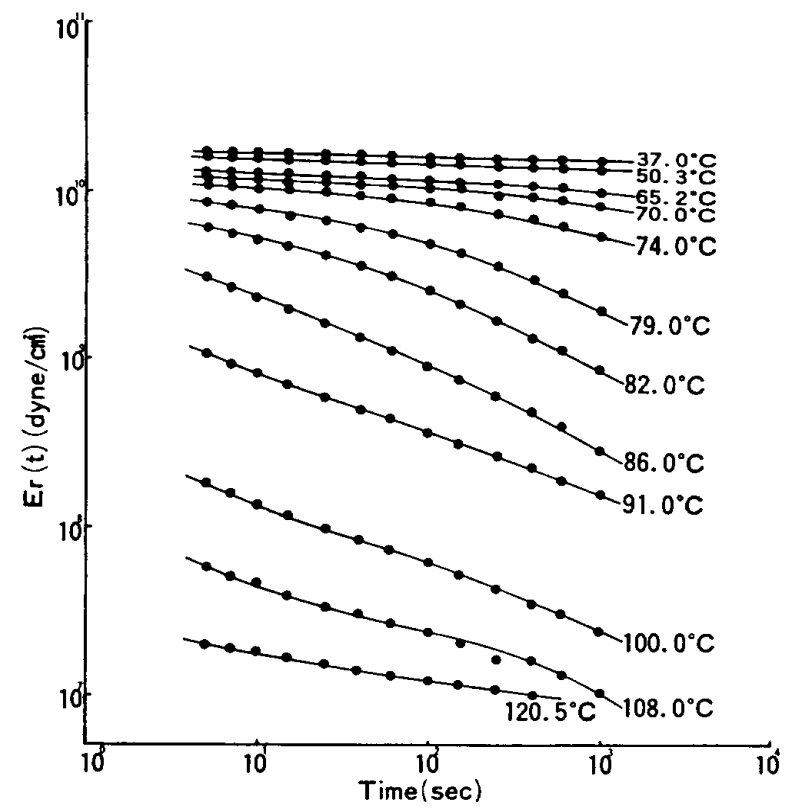

Fig. 3 Measured Stress Relaxation Modulus $\operatorname{Er}(\mathbf{t})$ vs. Time Curve of PP.O Specimen

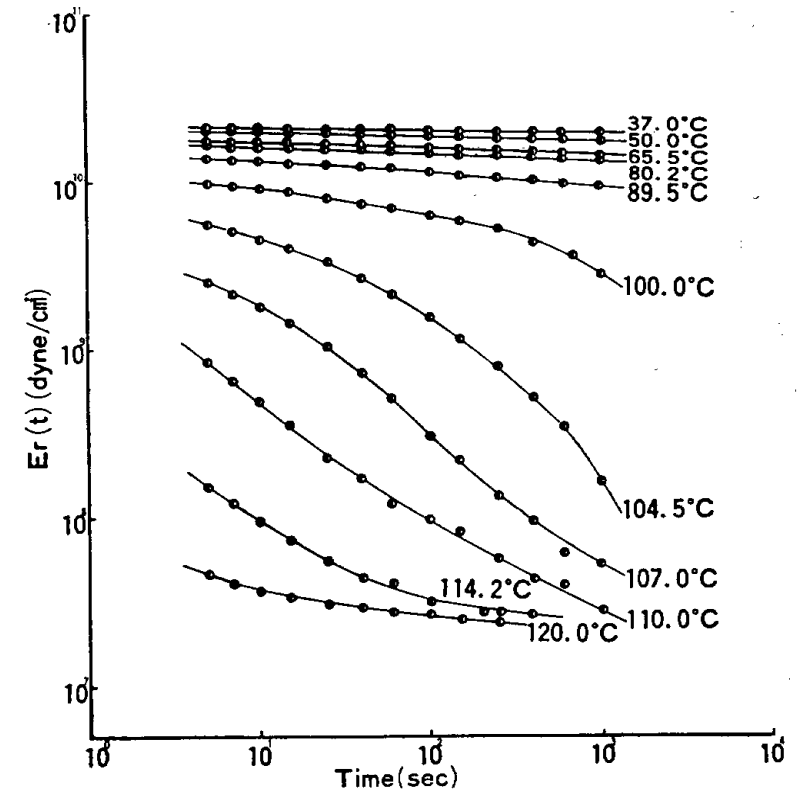

Fig. 4 Measured Stress Relaxation Modulus $\operatorname{Er}(t)$ vs. Time Curve of MP-O Specimen

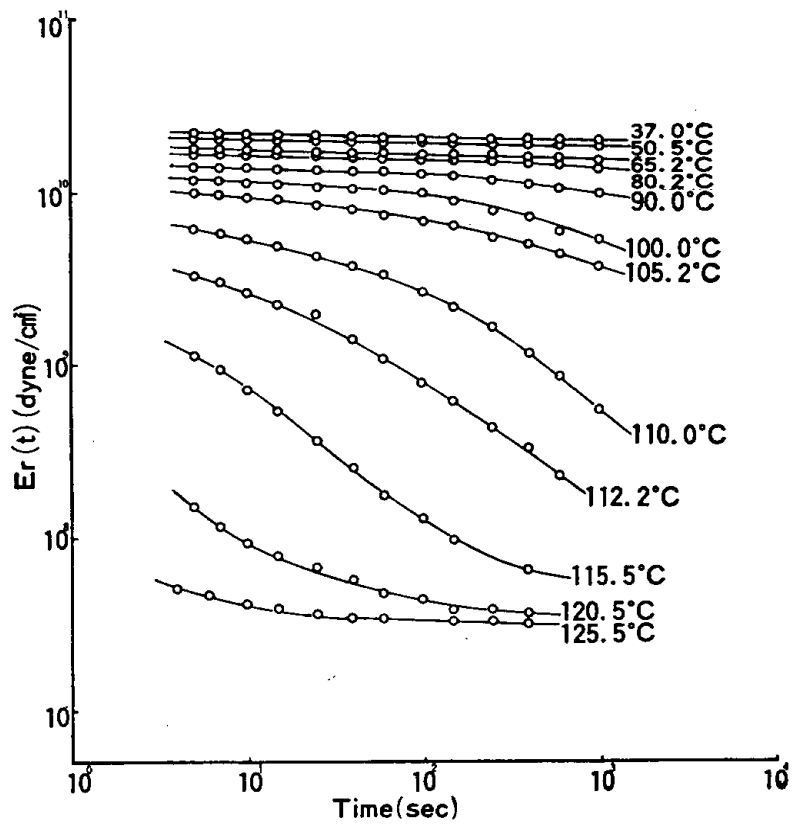

Fig. 5 Measured Stress Relaxation Modulus $\operatorname{Er}(t)$ vs. Time Curve of MM-O Specimen

ついでMP-O，MM-Oの順に緩和しにくくなる，MM 一Oのガラス転移温度は 3 試料中, 最も高く $115^{\circ} \mathrm{C}$ 付近 となった。

Fig. 6 はPP-O, MP - O , MM-Oの3 試料の10秒後 の緩和弾性率 $\operatorname{Er}(10)$ の温度分散を図示したものであ る. 各值はTable 5 亿示す。乙れによると緩和弾性率一 温度曲線が1010dyne $/ \mathrm{cm}^{2}$ の線をよぎる温度はPPーO が $75^{\circ} \mathrm{C}, \mathrm{MP}-\mathrm{O}$ では $98^{\circ} \mathrm{C}, \mathrm{MM}$ 一では $103^{\circ} \mathrm{C}$ よる 


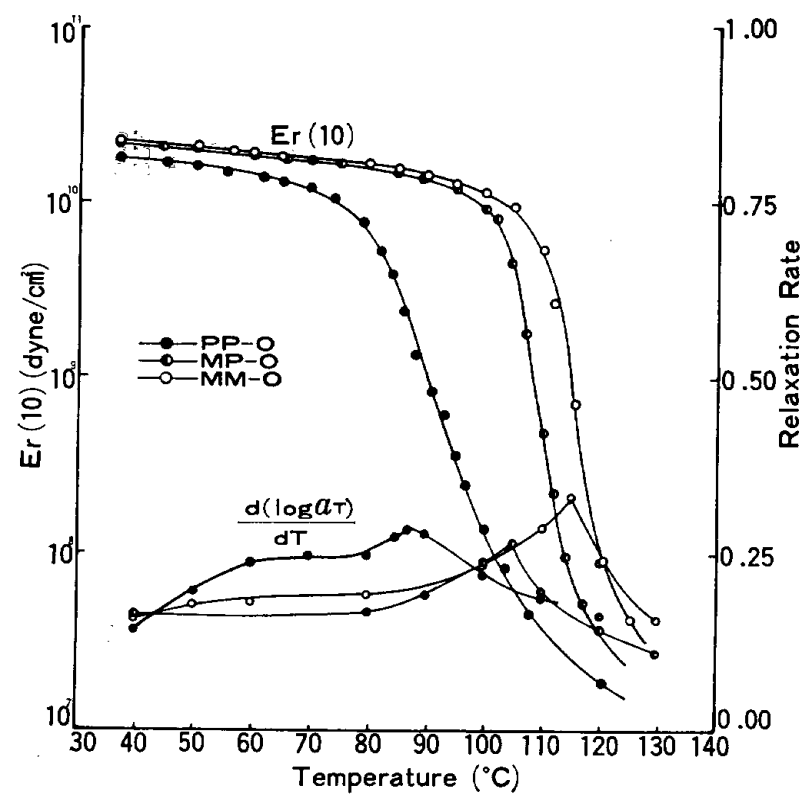

Fig. 6 Temperature Dependence of Stress Relaxation Modulus $\operatorname{Er}(10)$ and Relaxation Rate of unsoaked Specimen

ことがわかる。また転移領域（この場合，便宜的に弾性 率が $1 \times 1010$ dyne $/ \mathrm{cm}^{2}$ から $1 \times 10^{8}$ dyne $/ \mathrm{cm}^{2}$ まで低 下する領域をさすものとする) は $\mathrm{MP}-\mathrm{O}, \mathrm{MM}-\mathrm{O}$ が $16^{\circ} \mathrm{C}$ 幅なのに対し $\mathrm{PP}$ 一は $27^{\circ} \mathrm{C}$ 幅上なった。

試料を acetone, benzene, xylene, eugenol に長時 問浸漬した場合はクラック型の溶解をするのに対し chloroform, ethyl alcohol に浸漬した場合は澎閏型の溶解 をする傾向を示した。

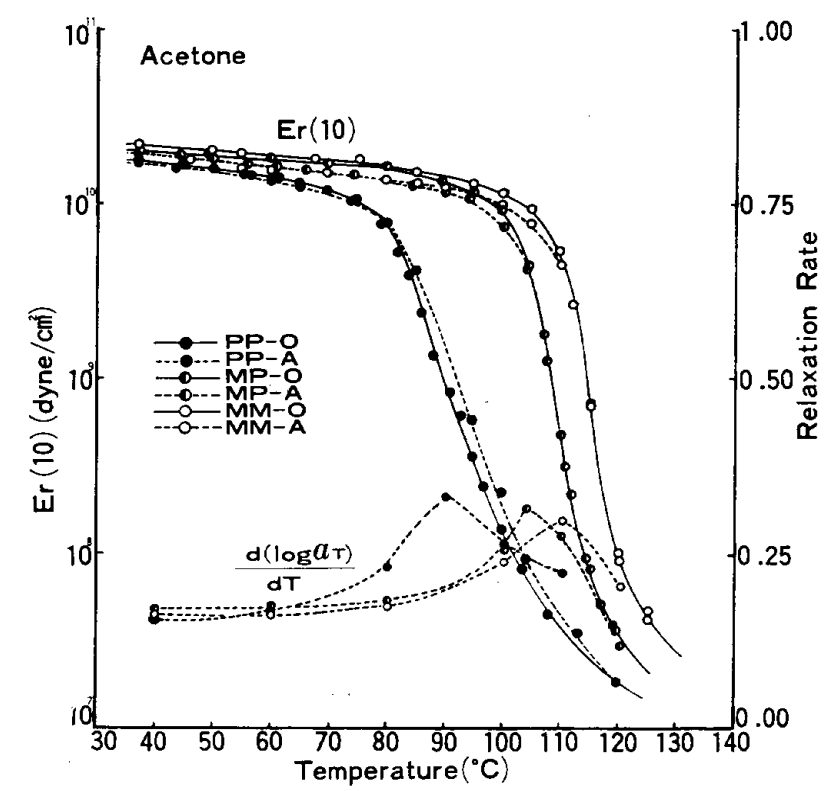

Fig. 7 Temperature Dependence of Stress Relaxation Modulus $\operatorname{Er}(10)$ and Relaxation Rate of Specimen soaked in Acetone

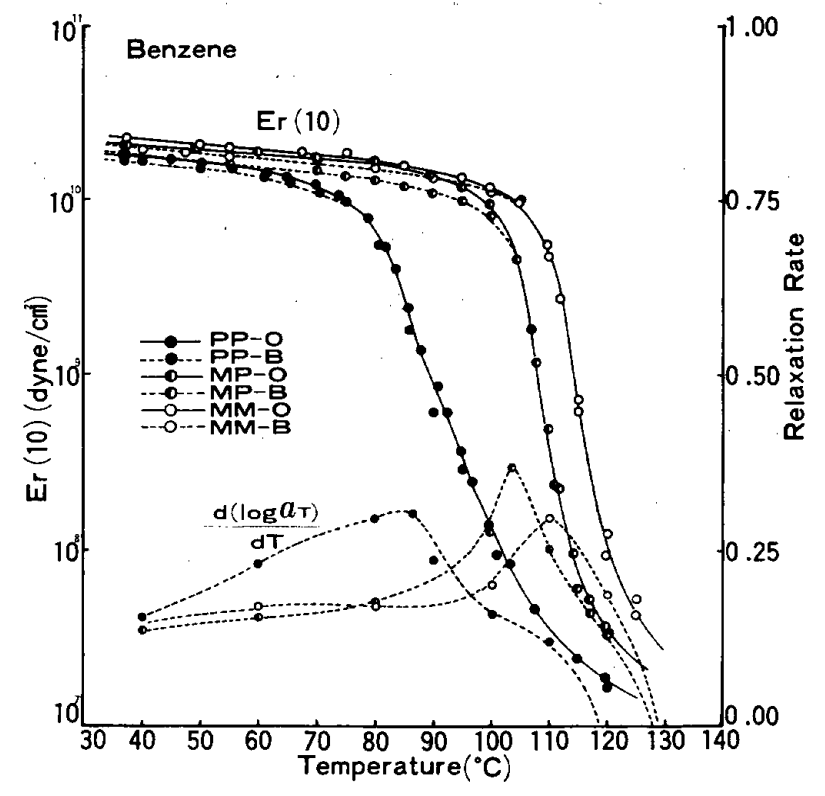

Fig. 8 Temperature Dependence of Stress Relaxation Modulus $\operatorname{Er}(10)$ and Relaxation Rate of Specimen soaked in Benzene

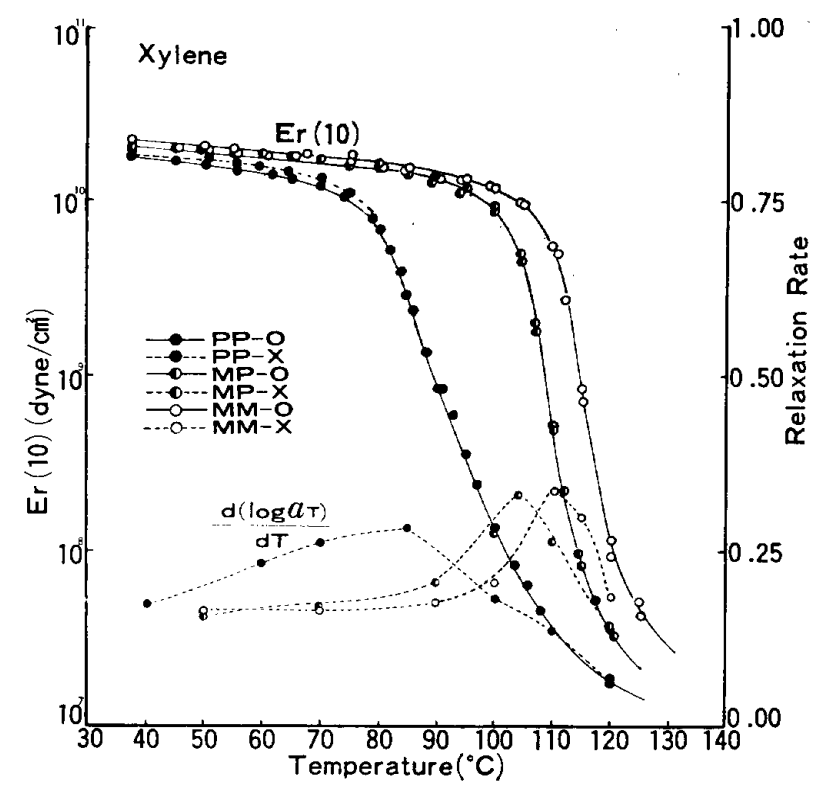

Fig. 9 Temperature Dependence of Stress Relaxation Modulus $\operatorname{Er}(10)$ and Relaxation Rate of Specimen soaked in Xylene

Fig. 7〜13 は有機溶媒 (acetone, benzene, xylene, chloroform, eugenol, ethyl alcohol) および水にPP, MP, MM をそれぞれ Table $1 に$ 示した時間だけ浸漬し た試料の緩和弾性率の温度分散を図示したものである。

acetome, benzene, xylene, eugenol に浸漬した試 料は常温付近での弾性率は下がるが，転移領域での弾性 


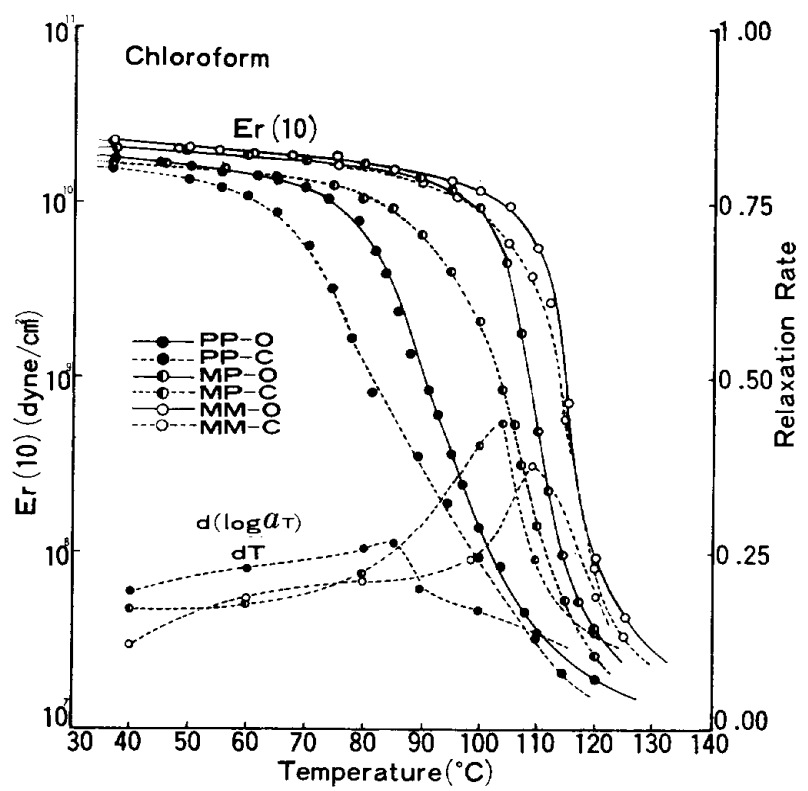

Fig. 10 Temperature Dependence of Stress Relaxation Modulus $\operatorname{Er}(10)$ and Relaxation Rate of Specimen soaked in Chloroform

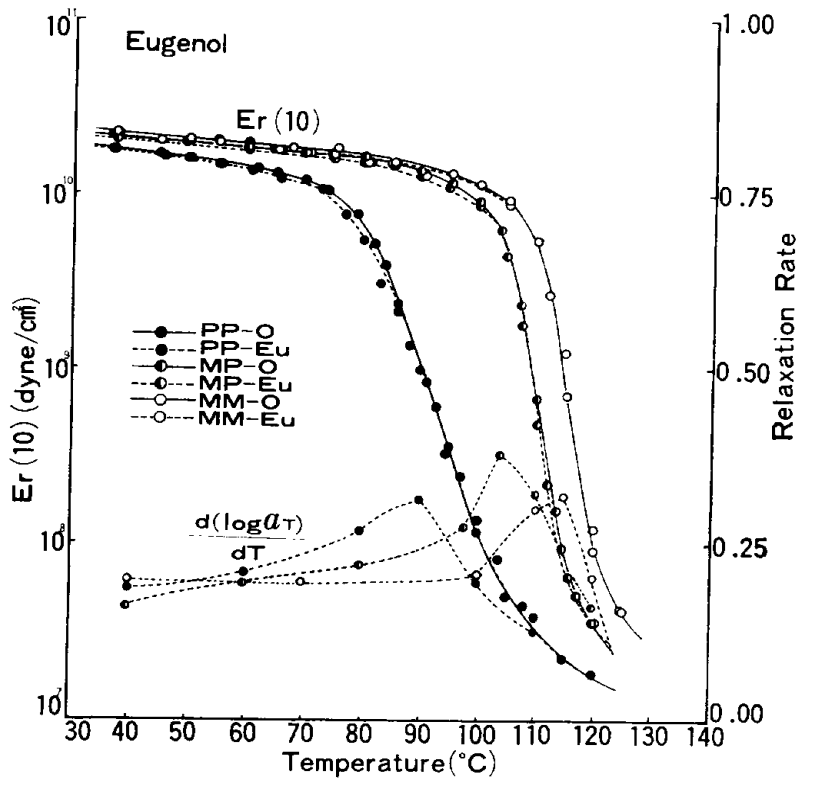

Fig. 11 Temperature Dependence of Stress Relaxation Modulus $\operatorname{Er}(10)$ and Relaxation Rate of Specimen soaked in Eugenol

率には変化を受けない，chloroform 浸漬試料では常温 付近での弾性率だけでなく転移領域での弾性率む低下す る. しかし ethyl alcohol に浸漬した試料はいずれも弾 性率が上昇し緩和しにくくなった。乙の傾向は PP-Et において特に著しい，水に浸漬した試料では無浸漬試料 とほとんど変わらない挙動を示した。各值はTable 6〜

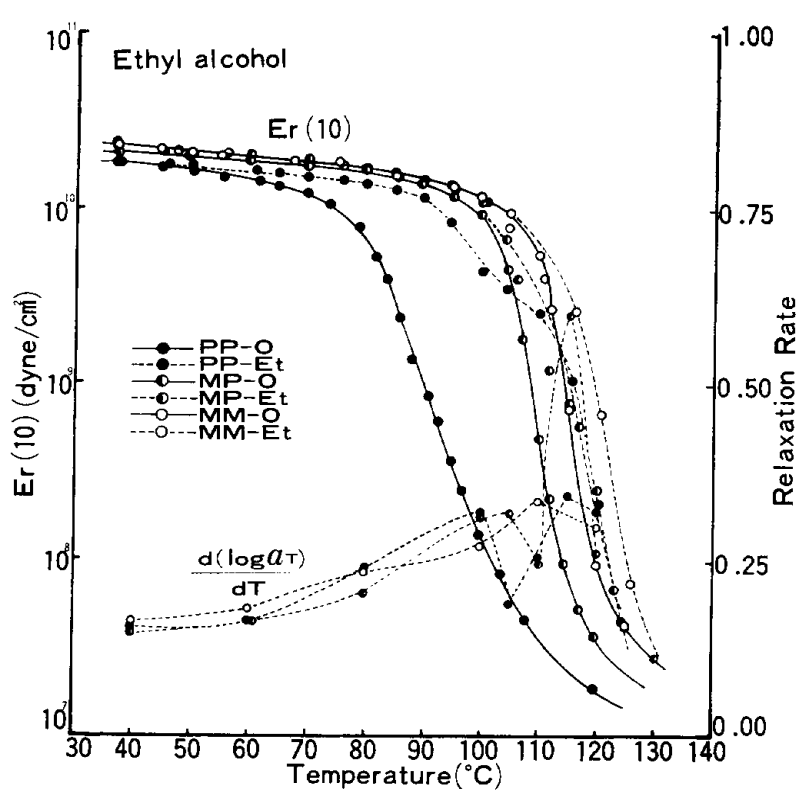

Eig. 12 Temperature Dependence of Stress Relaxation Modulus $\operatorname{Er}(10)$ and Relaxation Rate of Specimen soaked in Ethyl alcohol

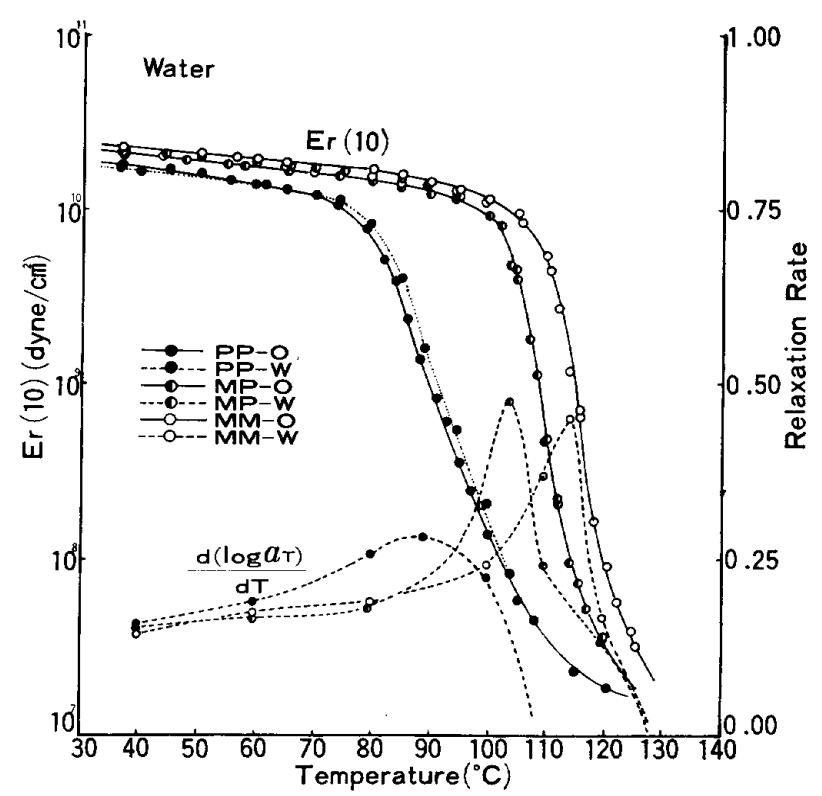

Fig. 13 Temperature Dependence of Stress Relaxation Modulus $\operatorname{Er}(10)$ and Relaxation Rate of Specimen soaked in Water

12に示す,

Fig. 14〜21 は無浸漬試料，浸漬試料について種々の 温度での緩和弾性率一時間曲線を $37^{\circ} \mathrm{C}$ での曲線に重ね 合わせたマスターカーブおよびてれを図上微分りて求め た緩和スペクトルを図示したものである.

これによると無浸漬試料の緩和スペクトルのピークの 


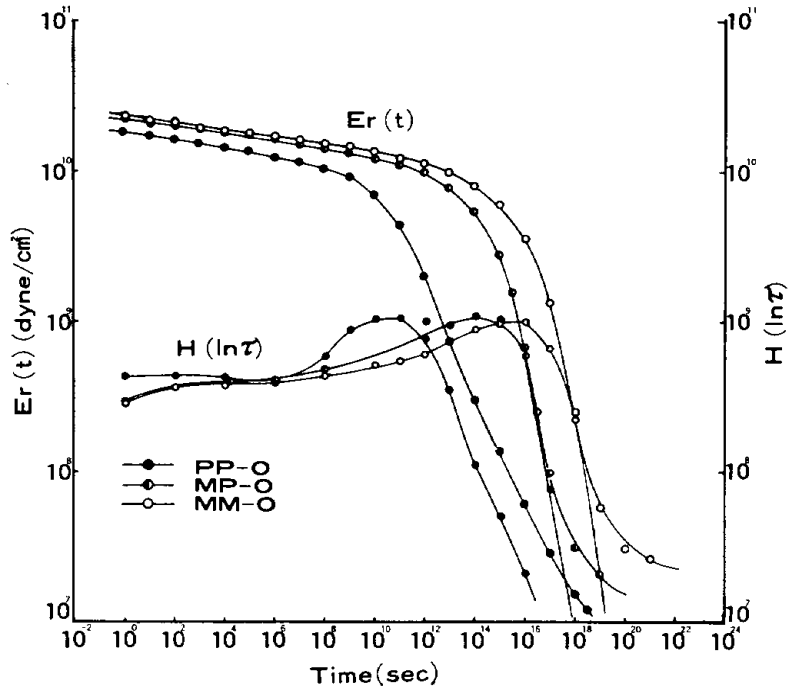

Fig. 14 Master Curve and Relaxation Time Spectrum of unsoaked Specimen

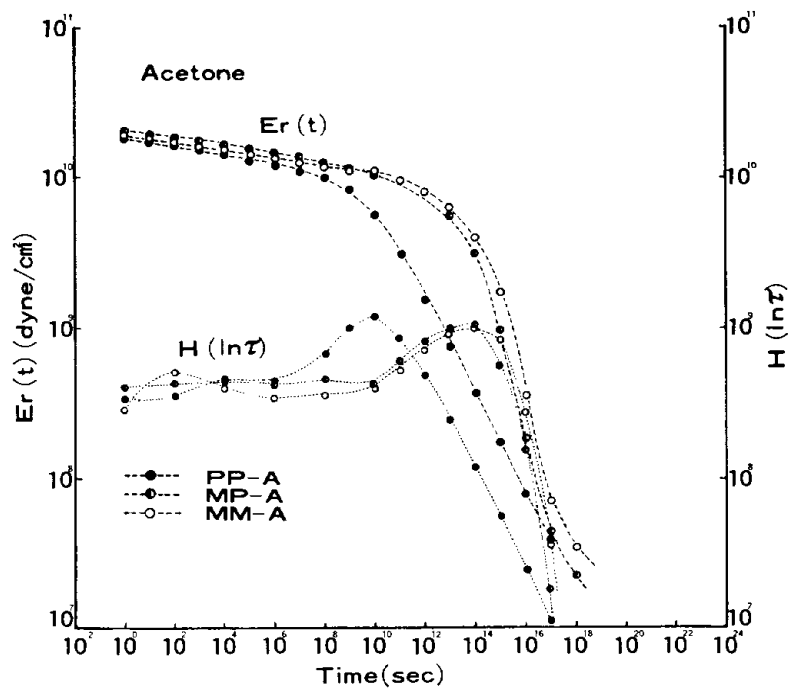

Fig. 15 Master Curve and Relaxation Time Spectrum of Specimen soaked in Acetone

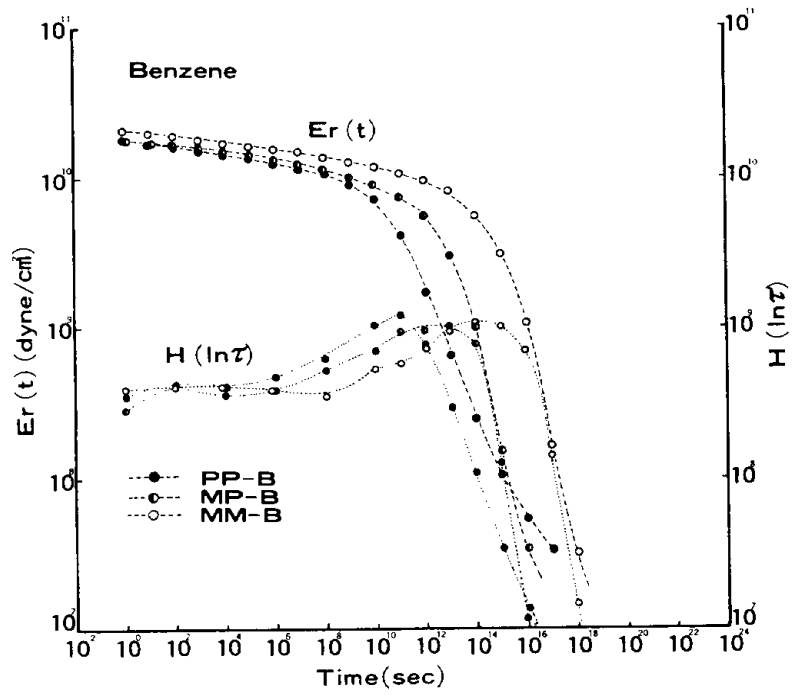

Fig. 16 Master Curve and Relaxation Time Spectrum of Specimen soaked in Benzene

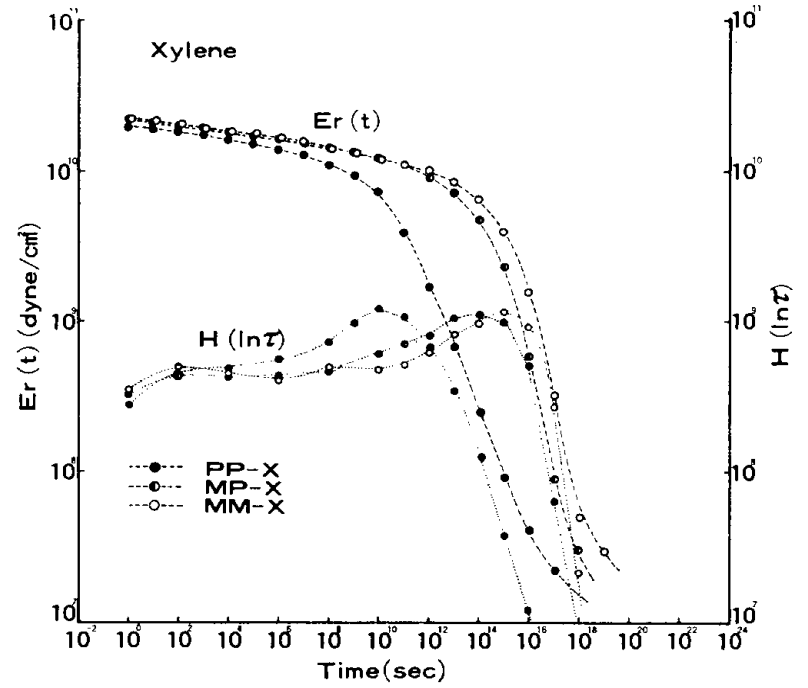

Fig. 17 Master Curve and Relaxation Time Spectrum of Specimen soaked in Xylene

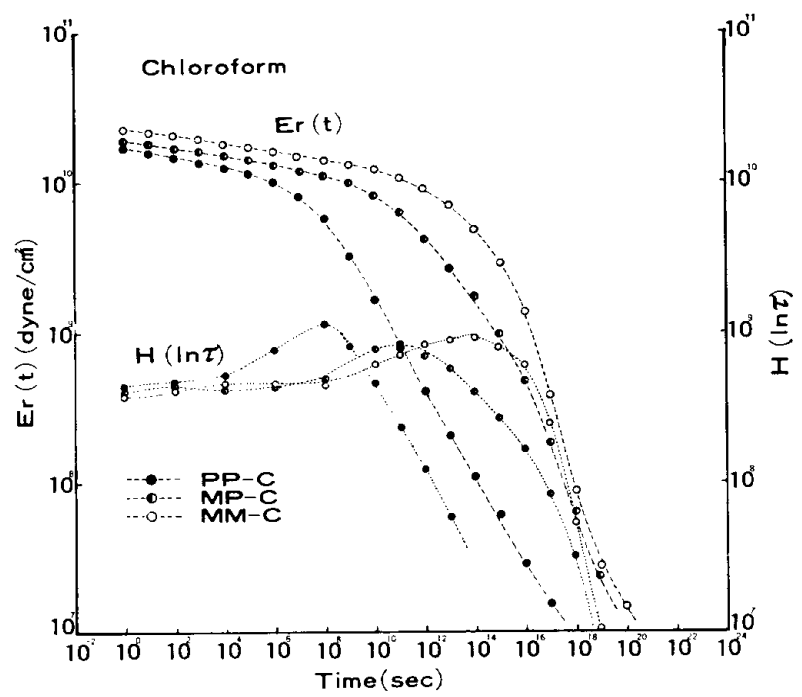

Fig. 18 Master Curve and Relaxation Time Spectrum of Specimen soaked in Chloroform

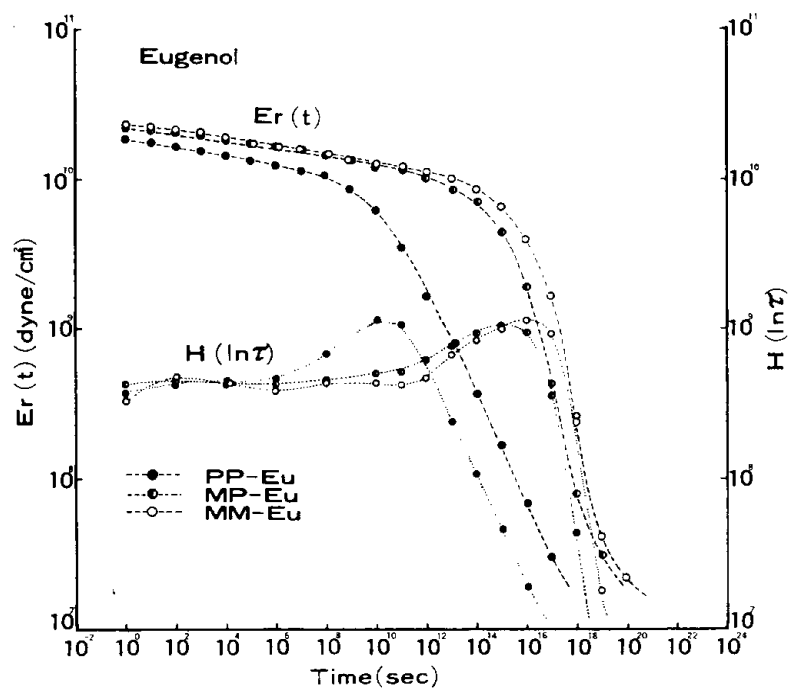

Fig. 19 Master Curve and Relaxation Time Spectrum of Specimen soaked in Eugenol 


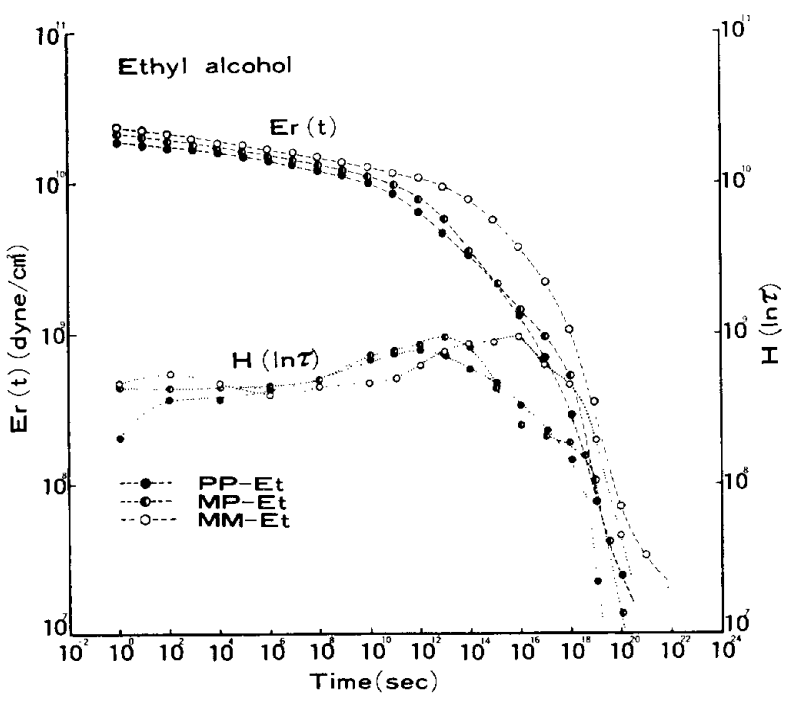

Fig. 20 Master Curve and Relaxation Time Spectrum of Specimen soaked in Ethyl alcohol

位置は PP-OがIO11sec, MP-O が1014sec, MM-Oが 1016 sec である. 水および ethyl alcohol 以外の有機溶 媒に浸漬した試料の緩和スペクトルのピークの位置はい ずれも短時間側に移行し，なかでも chloroform に浸漬 した試料では $\mathrm{PP}-\mathrm{Cが103} \mathrm{sec,} \mathrm{MP-Cが1011sec,} \mathrm{MM}$ 一Cが1014sec と大きく短時闃側に移行し, 緩和しやすく なっている。 ethyl alcohol に浸漬した試料ではピーク の位置は PP-Etが1012sec, MP-Etが1013sec, MMEt が $103 E s e c$ なる值を示し, PP-Et の場合のみ長時間 側へ移行していて明らかに䌅和しにくくなっているとい えるが，MP-Et， MM-Et 亿おいてもその曲線の形状 からすると必ずしあ緩和しやすくなっているとはいえな い. 各值は Table13 18 に示す.

この際，時間軸に沿ってシフトさせた量と温度との関 係の曲線を更に図上微分して $\left\{\frac{\mathrm{d}\left(\log a_{\mathrm{T}}\right)}{\mathrm{dT}}\right\}$ を求め, その ピークを与える温度を $\mathrm{Tg}$ とした．各温度に対する $\left\{\frac{\mathrm{d}\left(\log a_{\mathrm{T}}\right)}{\mathrm{dT}}\right\}$ の值は Table 19〜25 亿示す. Fig. 6〜13 にてれを図示している。

$\mathrm{Tg}$ での基準曲線上に $\mathrm{Tg}$ 以上の温度で得られる曲線 を互に重㸚合わせて一本の合成曲線とした後, WLF 式 を用いてそれぞれの緩和過程におりる見かけの活性化工 ネルギーを求めた．各值は Table 27 に示し，Fig. 22 〜28 に図示した。

この図によると acetone, benzene, xylene, chloroform, eugenol に浸漬した試料の緩和過程における見

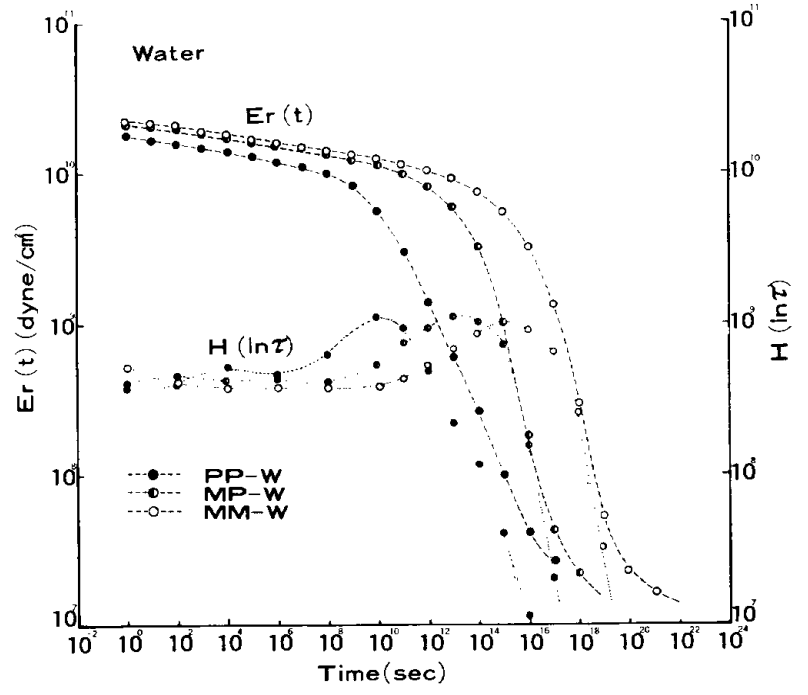

Fig. 21 Master Curve and Relaxation Time Spectrum of Specimen soaked in Water

かけの活性化エネルギーは PP, MP, MM 3 試料とも に低下するが, ethyl alcohol に浸漬した試料ではPP試 料 (PP-Et) において特に活性化エネルギーの上昇が 見られた。水に浸漬した試料の活性化エネルギーは無浸 漬試料と比較して大差なかった。

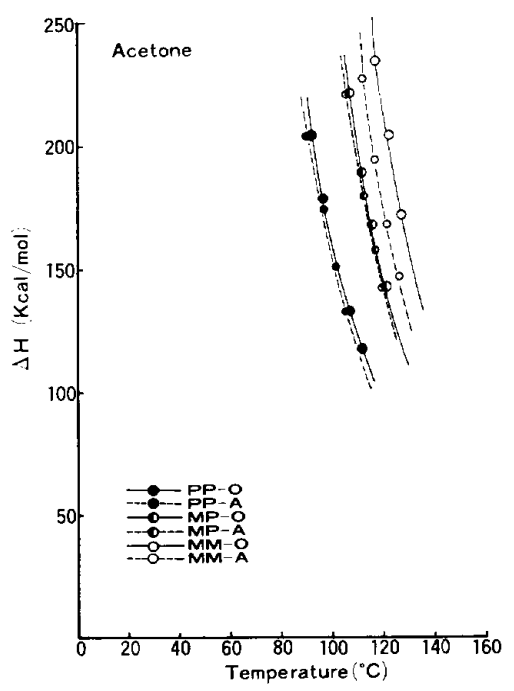

Fig. 22 Apparent Activation Energy on Strèss Relaxation Process of Specimen soaked in Acetone 


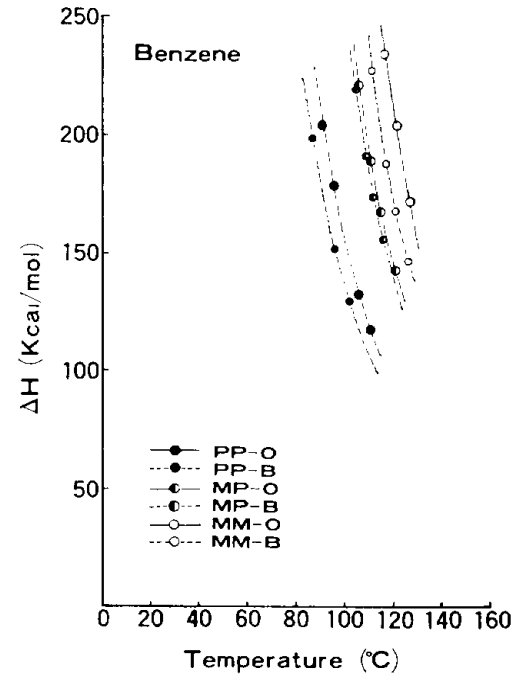

Fig. 23 Apparent Activation

Energy on Stress Relaxation Process of Specimen soaked in Benzene

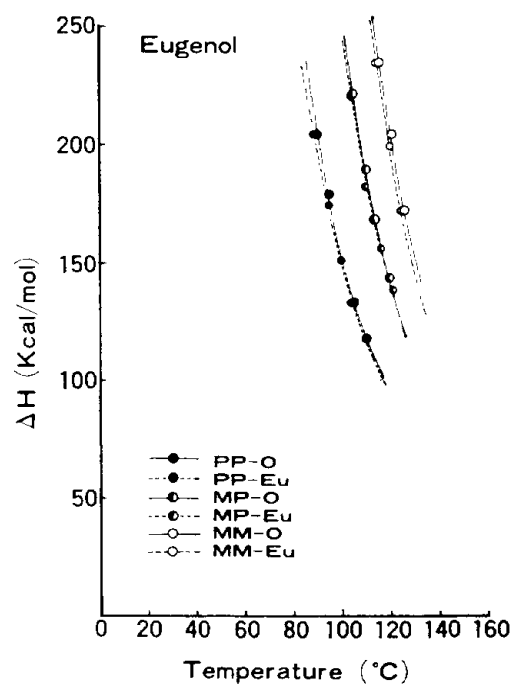

Fig. 26 Apparent Activation

Energy on Stress Relaxation Process of Specimen soaked in Eugenol

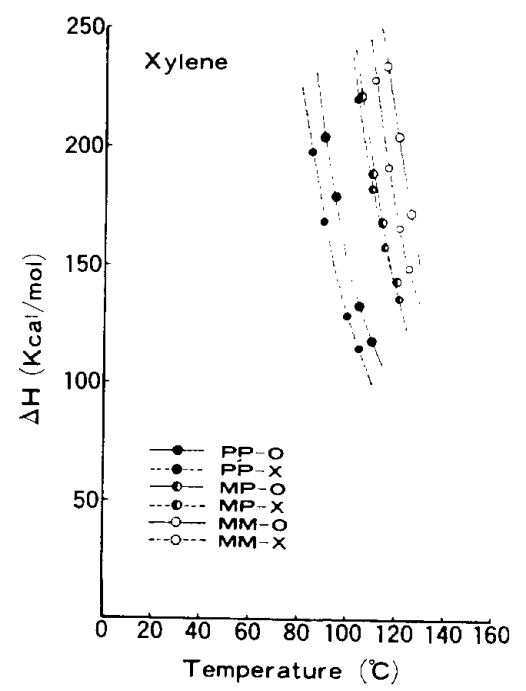

Fig. 24 Apparent Activation

Energy on Stress Relaxation Process of Specimen soaked in Xylene

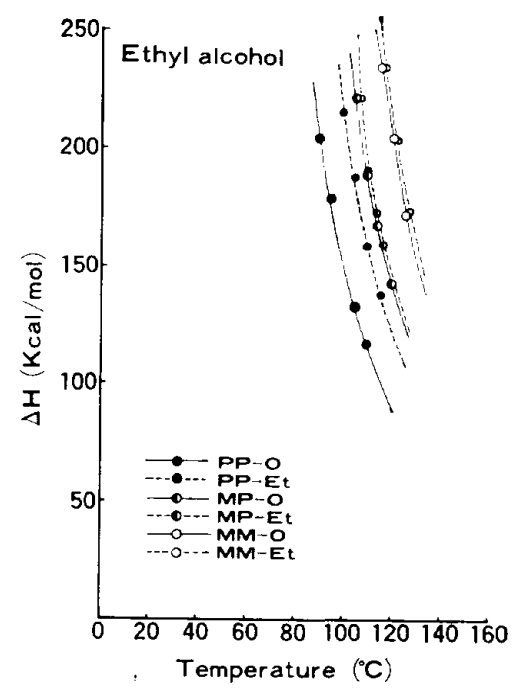

Fig. 27 Apparent Activation

Energy on Stress Relaxation Process of Specimen soaked in Ethyl alcohol

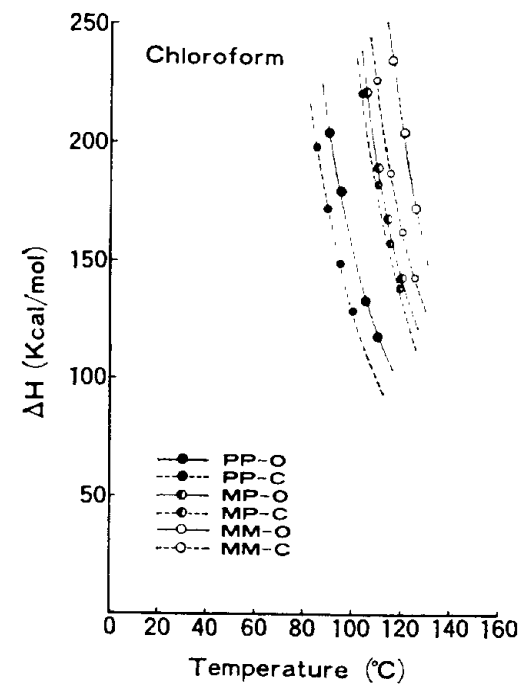

Fig. 25 Apparent Activation

Energy on Stress Relaxation Process of Specimen soaked in Chloroform

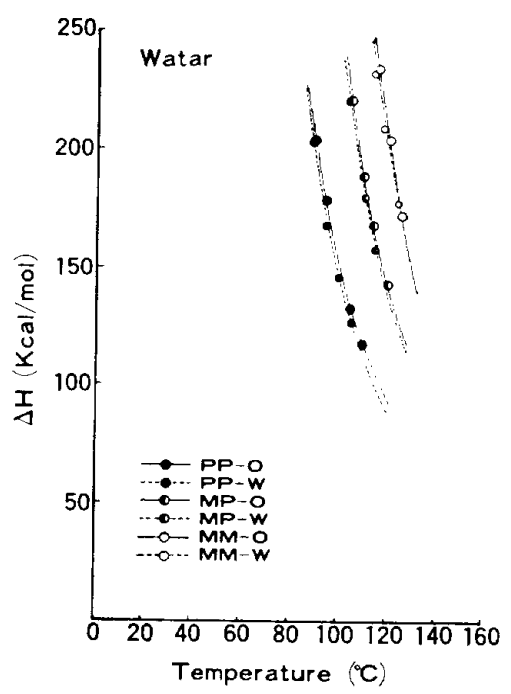

Fig. 28 Apparent Activation

Energy on Stress Relaxation Process of Specimen soaked in Water

\section{VII 考察}

まず無浸漬試料相互間の差㝜について考察する。 $\mathrm{PP}-\mathrm{O}$ は分子鎖のエンタングルメントが少ないため 比較的低温でも緩和が起こりやすいが， MP-O， MM 一O はこのようなエンタングルメントの程度が PP-O に比し進んでいると考えられるので， Tg 付近になるま
では緩和しにくく，いったん Tgに達すれば急激に緩和 が起こることが予想される。転移領域での温度幅が PP -Oが $27^{\circ} \mathrm{C}, \mathrm{MP}-\mathrm{O}, \mathrm{MM}-\mathrm{O}$ が $16^{\circ} \mathrm{C}$ であるのは乙 のためと思われる。

次に浸漬試料であるが，試料によって溶媒に浸漬する 時間が異なるので溶媒相互間での挙動の変化を比較する ことは困難である。しかし無浸漬試料の粘弾性的挙動が 
いろいろなタイプの溶媒処理をすることによりどのよう に変化するかを検討することは十分可能と考える.

有機溶媒による溶解現象には膨潤型とクラック型の二 つのタイプがあり, 前者には chloroform, ethyl alcohol 後者には acetone, benzene, xylene, eugenol が

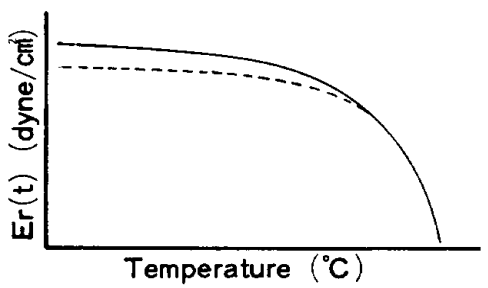

(a)

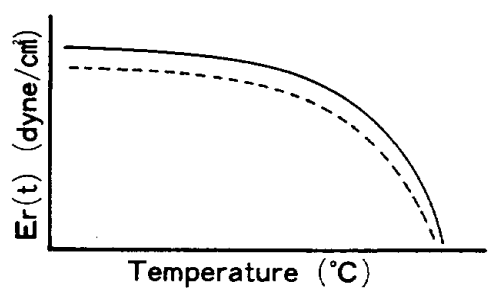

(b)

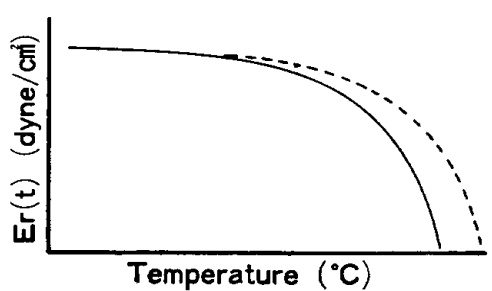

(c)

Fig. 29 Schematic Temperature Dependence Curve of Stress Relaxation Modulus

属する. 本実験の溶媒処理の効果は Fig. 29 に模式的に 示した三つのタイプに分けて考元られる.（a）は常温付 近での弾性率のみが低下し $\mathrm{Tg}$ には大きな差異を与えな いタイプである.（b) は常温付近での弾性率， Tg とも に低くなるタイプである．（c）は常温付近での弾性率は 余り変化しないで $\mathrm{Tg}$ のみが, 高温側に移行するタイプ である。

溶媒処理により現われた挙動の変化をこの模式図をも とに説明しよう.

Fig. 7〜13 において明らかなように acetone, benzene, xylene, eugenol の各溶媒に浸漬した試料は Fig.29 の（a)のタイプに属し，Tg の変化はほとんよ゙ 見られず，常温付近で緩和弾性率 $\operatorname{Er}(10)$ の低下がわず
かに見られるのみである。これらの緩和スペクトルのピ 一クの位置は Fig. 15〜17，19 に示すようにわずかに 短時間側に移行している．緩和過程における見かけの活 性化エネルギーも Fig. 22〜24，26 から明らかなよう にわずかに小さくなっているに過ぎない，てれは試料を 溶媒に浸漬した際に低分子量の部分を溶出し，その分だ け弾性率の低下が見られるためであろう。

chloroform に浸漬した試料は Fig. 29 の(b)のタイ プになったが，てれは溶媒の親和力が大きく，試料の溶 解が著しく起とるためと考えられる。 acetone, benzene, xylene, eugenol に浸漬した場合も Table 1 に示 した適当な浸漬時間を越えると Fig. 29 の(b)の型に似 た挙動を示すと想像されるが，その場合には試験片周辺 にクラックを多数認め得るようになろう.

ethyl alcohol に浸清した試料は Fig. 29 の(c)のタ イプを示した。これは試料が橵澗する過程で分子鎖のエ ンタングルメントが進み物理的架橋構造29.30)が新たに形 成されるためと考えられる．単にポリマーのみを加熱加 王して互に融着にた分子銷のエンタングルメントが比較 的少ない PP 試料に，最もその効果が現われるのは当然 であろう。

水に浸漬した 試料は無浸漬試料とほぼ 同じ 挙動を示 す.わずか滛和スペクトルのピークの位置が短時間側 に移行するのみである。試料の溶解がほとんど無視でき ることを示している。

\section{VIII 結 論}

以上の考察から次のととが結論づけられる。

1）有機溶媒に溶解する際のタイプとして膨潤型とク ラック型がある.

2) acetone, benzene, xylene, eugenol を用いて クラックが入らぬ程度の時間で溶解処理を行なった試 料は常温付近での弾性率が低下するのみで，Tg には 影響を受けない.

3） chloroform に浸漬した試料は膨潤型で常温付近 での弾性率， Tg ともに下がる。

4) ethyl alcohol に浸漬した試料に膨潤し，弾性率 の増大と $\mathrm{Tg}$ の上昇をきたす。この傾向は融着ポリマ 一試料の場合, 特に著しい。乙れは分子銷のエンタン グルメントが進むためと考えられるが膨潤型との関連 は明らかでない。

5）水に浸漬した試料の挙動は無浸漬試料と同じであ る.

6）モノマーを重合した試料，モノマー・ポリマーテ 
クニックで重合した試料はポリマー粉末を融着成形した 試料に比べて縀和しにくい。

\section{IX 臨床的考察}

現在歯科用レジンに用いられているポリメタクリル酸 メチルの粘弾性的性筫が，有機溶媒浸漬により試料の一 部が溶出した場合どのように変化するかを実験し検討し た。

これによる上 PP 試料は分子鎖のエンタングルメント や分子量が MP，MM試料に比へてはるか汇少なく，溶 媒に刘しても弱いととが明らかとなった。

その点, 現在霜科領域で用いら机ているモノマー・ポ リマー重合法により作製される MP 試料は MM 試料之 比較して，分子銧のエンタングルメントや分子量の点で あ余り遴色なく，しかも寸法安定性があり，術式が容易 であるという点を考虑すると歯科用として最適の材料と いえよう。

臨床的に用いられることの多い eugenol は，3時閒 前後の浸清では常温付近での弾性率がわずか低下する のみであるが，てれより長時間の浸漬では大きなクラッ クを生じるようになり，更に長時間（6時間以上）浸漬 すると，本実験に使用した試験片の大きさでは，完全に 溶失してしまう。したがって eugenol が畨科用レジン に対して禁忌とされているのは当然であろう。

稿を終わるに当り，本研究に終始御慈切なる街指導と 御校閲を賜った恩師林一郎教授に深甚なる感謝の意を表 わします。また実験上数多くの御教示をいただいた井上 勝一郎助教授に衰心より謝意を棒げるととあに，本研究 に種々御協力いただいた小園䟗夫先生, 柿川宏先生, 梶 木干秋さんに対」，心からの謝意を表わします。

\section{引用 文 献}

1. Tobolsky, A. V. : Properties and structure of polymers, John Wiley \& Sons, 1962.

2. Woodward, A. E. : The dynamic mechanical properties of high polymers at low temperatures. Fortschr. Hochpolym. Porsch., Bd. I : 114 158, 1958.

3. Bueche, F. : Physical properties of polymers, John Wiley \& Sons, 1960.

4. Ferry, J. D. : Viscoelastic properties of poly mers, John Wiley \& Sons, 1960.

5. Tylman, S. D. and Peyton, F. A. : Acrylic and Other Synthetic Resins Used in Dentist- ry, I18, J. B. Lippincott Co, Philadelphia, 1946.

6. Peyton, F. A. and Mann, W. R. : Acrylic and Acrylic-Styrene Resins, Their Properties in Relation to Their Uses as Restorative Materials, J. A. D. A. $29:$ 1852 1864, 1942.

7. 林 一郎, 井上勝一郎: $37^{\circ} \mathrm{C}$ 水中における市販床 用レジンの粘弾性的挙動, 雪科理工学倠誌 $8: 89$ $\sim 92,1962$.

8. 浅見 高：アクリル樹脂，85〜88，日刊工業新聞 社, 東京, 1970.

9. 井上勝一郎, 林 一郎：歯科用レジンの 動的粘弾 性, 迷科理工学雑誌 $9: 11 \sim 14,1968$.

10. Brauer, G. M. and Sweeney, W. T. : Sorption of Water by Polymethyl Methacry late, Modern Plastics 32: 138 144, 1955.

11. Nielsen, L. E.：高分子の力学的性質, 74, 化 学同人, 京都, 1970.

12. 高分子学会・他編：レオロジー測定法, 150〜159, 共立出版, 東京, 1965 .

13. Nielsen, L. E. : 高分子の力学的性質, 74 83, 化学同人, 京都, 1970.

14. 井上勝一郎: Fundamental studies on viscoelasticity of polymethyl methacrylate polymerized by monomer-polymer technique, 九州菌科 学会雑誌 $25: 445 \sim 447,1972$.

15. 後藤廉平・他：レオロジーとその応用，73〜83, 共立出版, 東京, 1969.

16. Nielsen, L. E. : 高分子の力学的性質, 85〜91, 化学同人, 京都, 1970.

17. Bueche, F. : Physical properties of polymers, 169 174, John Wiley \& Sons, New York, 1962.

18. 金丸 競: 高分子物性工学, 82 85, 地人書館, 東京, 1968.

19. 高分子学会編: 高分子の物理学, 146～148, 地人 書館, 東京, 1963.

20. 井上勝一郎 : Fundamental studies on viscoelas ticity of polymethyl methacrylate polymerized by monomer-polymer technique, 九州歯科 学会雑誌 $25 ： 446 \sim 447,1972$.

21. 神戸博太郎・村上謙吉：応用レオロジー，118〜 120, 日刊工業新聞社, 東京, 1963 . 


\begin{tabular}{|c|c|c|c|c|c|c|c|c|c|c|c|c|c|c|}
\hline \multirow{5}{*}{ 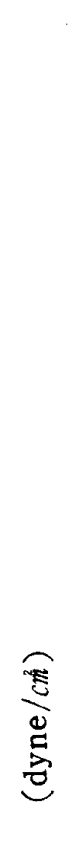 } & 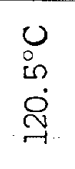 & 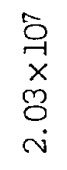 & 今े & $\begin{array}{l}\infty \\
\infty \\
-i\end{array}$ & $\stackrel{M}{\stackrel{N}{-}}$ & in & $\underset{-i}{\stackrel{H}{*}}$ & $\begin{array}{l}\vec{m} \\
\text { ri }\end{array}$ & $\underset{\sim}{\stackrel{0}{N}}$ & $\begin{array}{l}\infty \\
\stackrel{-1}{-1} \\
-1\end{array}$ & $\begin{array}{l}8 \\
\\
-i\end{array}$ & $\stackrel{-1}{0}$ & 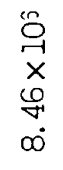 & \\
\hline & $\begin{array}{l}0 \\
0 \\
0 \\
\infty \\
0 \\
\stackrel{्}{-}\end{array}$ & 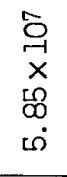 & $\begin{array}{l}\underset{N}{N} \\
\dot{\omega}\end{array}$ & $\begin{array}{l}\mathscr{O} \\
\dot{\nabla}\end{array}$ & $\begin{array}{l}\overrightarrow{0} \\
\stackrel{+}{*}\end{array}$ & $\begin{array}{l}\stackrel{\mathscr{P}}{\dot{m}} \\
\dot{3}\end{array}$ & $\begin{array}{l}\stackrel{8}{\circ} \\
\dot{m}\end{array}$ & $\begin{array}{l}\stackrel{\infty}{心} \\
\stackrel{\sim}{\sim}\end{array}$ & $\stackrel{\mathscr{q}}{\stackrel{\text { i }}{i}}$ & $\begin{array}{l}\vec{j} \\
\dot{i}\end{array}$ & $\begin{array}{l}80 \\
\stackrel{0}{-1}\end{array}$ & $\begin{array}{l}\hat{0} \\
\text {-i }\end{array}$ & $\begin{array}{l}\text { ले } \\
\text { - }\end{array}$ & \\
\hline & $\begin{array}{l}0 \\
0 \\
\circ \\
\dot{8} \\
\dot{-1}\end{array}$ & 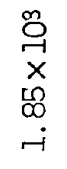 & $\begin{array}{l}\widetilde{W} \\
-i\end{array}$ & $\begin{array}{l}\text { g } \\
\text {-i }\end{array}$ & $\underset{i}{-i}$ & $\begin{array}{r}-\overrightarrow{0} \\
-i\end{array}$ & $\begin{array}{l}\stackrel{5}{\circ} \\
\stackrel{y}{x} \\
\stackrel{+}{+} \\
\infty\end{array}$ & $\begin{array}{l}\stackrel{\text { m}}{\sim} \\
\text {. }\end{array}$ & $\begin{array}{l}\underset{N}{N} \\
\dot{\omega}\end{array}$ & $\begin{array}{l}\widetilde{m} \\
\dot{m}\end{array}$ & $\begin{array}{l}\text { Fे } \\
\forall\end{array}$ & $\begin{array}{l}\vec{\omega} \\
\dot{m}\end{array}$ & $\begin{array}{l}\text { O } \\
\dot{m}\end{array}$ & $\begin{array}{l}\text { † } \\
\text { i }\end{array}$ \\
\hline & $\begin{array}{l}0 \\
0 \\
0 \\
\text { के }\end{array}$ & 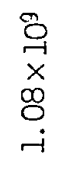 & 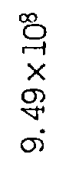 & $\begin{array}{l}\text { N } \\
\infty\end{array}$ & $\underset{r}{\stackrel{\sim}{r}}$ & $\begin{array}{l}5 \\
\dot{\theta}\end{array}$ & $\begin{array}{l}\stackrel{9}{1} \\
\dot{n}\end{array}$ & $\begin{array}{r}\tilde{\nabla} \\
\tilde{\nabla}\end{array}$ & $\begin{array}{l}\vec{H} \\
\dot{m}\end{array}$ & 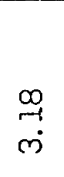 & $\underset{\sim}{\stackrel{\sim}{\sim}}$ & $\begin{array}{l}\stackrel{⿰}{\sim} \\
\stackrel{\sim}{v}\end{array}$ & $\begin{array}{l}\mathscr{O} \\
\text { O }\end{array}$ & $\overrightarrow{\underline{0}}$ \\
\hline & $\begin{array}{l}0 \\
0 \\
0 \\
0 \\
\infty\end{array}$ & 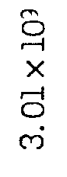 & $\begin{array}{l}\infty \\
@ \\
\dot{\sim}\end{array}$ & 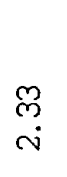 & $\stackrel{\tilde{\sigma}}{-i}$ & $\begin{array}{c}\mathcal{O} \\
-i\end{array}$ & $\begin{array}{l}\vec{m} \\
\text { ने }\end{array}$ & $\begin{array}{l}\stackrel{3}{\hookrightarrow} \\
-i\end{array}$ & $\begin{array}{l}\tilde{y} \\
\stackrel{1}{1} \\
\dot{x} \\
\stackrel{8}{0} \\
\dot{\sigma}\end{array}$ & $\begin{array}{l}8 \\
\stackrel{8}{\sim}\end{array}$ & $\begin{array}{l}\overrightarrow{0} \\
\dot{0}\end{array}$ & $\begin{array}{l}\infty \\
\dot{\nabla} \\
\dot{7}\end{array}$ & $\begin{array}{l}\infty \\
O \\
\dot{m}\end{array}$ & $\begin{array}{l}\infty \\
\infty \\
\stackrel{\sim}{\sim}\end{array}$ \\
\hline 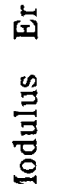 & $\begin{array}{l}0 \\
\circ \\
0 \\
\sim \\
\infty\end{array}$ & 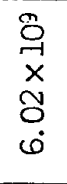 & $\begin{array}{l}8 \\
\dot{10}\end{array}$ & $\begin{array}{l}\vec{N} \\
\dot{\omega}\end{array}$ & $\underset{\nabla}{\vec{\nabla}}$ & $\begin{array}{l}\text { So } \\
\dot{+}\end{array}$ & 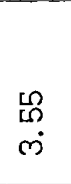 & $\begin{array}{l}8 \\
\text { ले }\end{array}$ & $\begin{array}{l}\stackrel{0}{\mathrm{D}} \\
\stackrel{\sim}{N}\end{array}$ & $\underset{\stackrel{M}{\sim}}{\stackrel{M}{\sim}}$ & $\begin{array}{l}\stackrel{8}{r} \\
-i\end{array}$ & $\begin{array}{l}\mathscr{e} \\
\stackrel{m}{-} \\
\end{array}$ & $\begin{array}{l}\stackrel{0}{-1} \\
-1\end{array}$ & 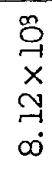 \\
\hline 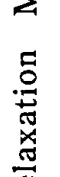 & $\begin{array}{l}0 \\
0 \\
0 \\
\text { Oे }\end{array}$ & 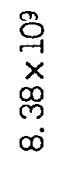 & $\begin{array}{l}\vec{A} \\
\infty\end{array}$ & 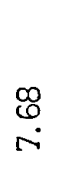 & $\underset{\stackrel{9}{-}}{\stackrel{9}{r}}$ & $\begin{array}{l}0 \\
0 \\
0\end{array}$ & $\begin{array}{l}\tilde{O} \\
\dot{\omega}\end{array}$ & $\begin{array}{l}\stackrel{g}{4} \\
\text { ம் }\end{array}$ & $\begin{array}{l}\mathscr{\infty} \\
\stackrel{+}{*}\end{array}$ & 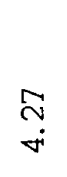 & 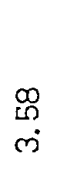 & $\begin{array}{l}\text { o } \\
\stackrel{i}{\sim} \\
\dot{\sim}\end{array}$ & $\begin{array}{l}\text { I } \\
\stackrel{i}{*}\end{array}$ & बे \\
\hline 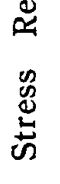 & $\begin{array}{l}0 \\
0 \\
0 \\
\text { ¿ }\end{array}$ & 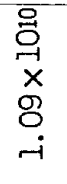 & کे & $\begin{array}{l}\stackrel{+}{O} \\
-i\end{array}$ & $\underset{+}{\overrightarrow{0}}$ & 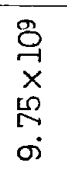 & $\begin{array}{l}\text { ले. } \\
\text { oे }\end{array}$ & $\begin{array}{l}\mathscr{O} \\
\infty \\
\infty\end{array}$ & $\begin{array}{l}\infty \\
\stackrel{\infty}{\infty}\end{array}$ & $\begin{array}{l}\varnothing \\
\infty \\
\infty\end{array}$ & $\begin{array}{l}\stackrel{\text { m }}{r} \\
\stackrel{\sim}{ }\end{array}$ & $\begin{array}{l}\overrightarrow{1} \\
\dot{\omega} \\
\dot{\omega}\end{array}$ & $\stackrel{7}{\oplus}$ & 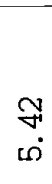 \\
\hline 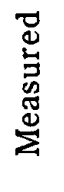 & $\begin{array}{l}0 \\
0 \\
0 \\
0\end{array}$ & 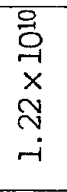 & $\underset{-i}{\stackrel{i}{r}}$ & $\underset{-i}{\stackrel{9}{-1}}$ & $\begin{array}{c}\stackrel{0}{-1} \\
\stackrel{-1}{-1}\end{array}$ & $\underset{-1}{\stackrel{H}{-1}}$ & $\begin{array}{l}ન-1 \\
\text { ન- }\end{array}$ & 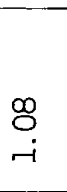 & $\begin{array}{l}\text { ठ } \\
\text {-i }\end{array}$ & $\begin{array}{l}8 \\
\text { Ö } \\
\text { - }\end{array}$ & 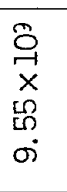 & $\begin{array}{l}\stackrel{0}{\sim} \\
\sigma\end{array}$ & $\begin{array}{l}\vec{i} \\
\infty\end{array}$ & $\begin{array}{l}\mathscr{Q} \\
0 \\
\infty\end{array}$ \\
\hline & $\begin{array}{l}0 \\
\stackrel{\circ}{0} \\
\stackrel{0}{0} \\
0\end{array}$ & 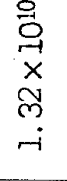 & $\vec{m}$ & $\begin{array}{l}\stackrel{\mathscr{N}}{\mathrm{H}} \\
\underset{-}{ }\end{array}$ & $\begin{array}{c}\stackrel{\infty}{\sim} \\
-i\end{array}$ & $\stackrel{\stackrel{n}{N}}{-i}$ & $\underset{-i}{\stackrel{M}{~}}$ & $\begin{array}{l}\stackrel{-1}{\sim} \\
-i\end{array}$ & $\begin{array}{l}\text { न् } \\
\text { - }\end{array}$ & $\begin{array}{l}\underset{-H}{H} \\
-i\end{array}$ & $\begin{array}{l}\vec{H} \\
-i\end{array}$ & 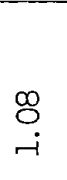 & 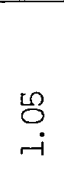 & 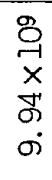 \\
\hline & $\begin{array}{l}0 \\
\text { m } \\
\dot{8} \\
\dot{0}\end{array}$ & $\begin{array}{l}\stackrel{9}{0} \\
- \\
x \\
\rightarrow \\
-1 \\
-1\end{array}$ & $\begin{array}{l}8 \\
-i\end{array}$ & $\begin{array}{l}\text { ธิ } \\
\text { กิ }\end{array}$ & $\begin{array}{l}0 \\
i n \\
i\end{array}$ & 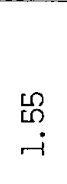 & 贯 & $\begin{array}{l}\overrightarrow{0} \\
-i\end{array}$ & $\begin{array}{l}\stackrel{9}{+} \\
-i\end{array}$ & $\begin{array}{l}\stackrel{0}{H} \\
\stackrel{-}{-}\end{array}$ & $\underset{\rightarrow}{\mathscr{P}}$ & $\begin{array}{l}\text { P } \\
\text {-i }\end{array}$ & 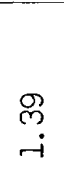 & 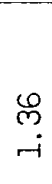 \\
\hline & $\begin{array}{l}0 \\
0 \\
\dot{m} \\
\dot{m}\end{array}$ & 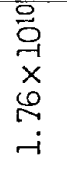 & 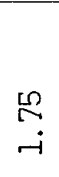 & 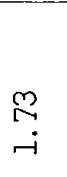 & $\begin{array}{l}\stackrel{R}{-} \\
\stackrel{-}{2}\end{array}$ & $\begin{array}{l}\text { of } \\
\text {-i } \\
-1\end{array}$ & $\stackrel{\tilde{G}}{-i}$ & $\begin{array}{l}\mathscr{\wp} \\
\stackrel{\leftrightarrow}{-1}\end{array}$ & $\begin{array}{l}\mathbb{E} \\
-i\end{array}$ & $\underset{\sigma}{\tilde{\sigma}}$ & $\begin{array}{l}8 \\
\stackrel{-}{-}\end{array}$ & $\begin{array}{l}\infty \\
\infty \\
-i \\
-i\end{array}$ & $\begin{array}{l}0 \\
\stackrel{\mathrm{L}}{\mathrm{r}}\end{array}$ & 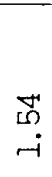 \\
\hline$\frac{2}{z}$ & $\underline{\underline{E}}$ & 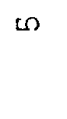 & $r$ & 옴 & $\stackrel{\leftrightarrow}{\hookrightarrow}$ & $\stackrel{\mathscr{\sim}}{\sim}$ & 아 & 8 & 움 & $\stackrel{\circ}{\stackrel{\leftrightarrow}{口}}$ & 品 & \& & 8 & 8 \\
\hline
\end{tabular}


22. Nielsen, L. E. : 高分子の力学的性質, II 15, 化学同人, 京都, 1970.

23. 後藤廉平・他：レオロジーとその応用，95～99, 共立出版，東京，1969，

24. 中川鶴太郎：レオロジー, 163〜170, 岩波書店, 東京, 1960 .

25. Tobolsky, A. V. : Properties and Structure of Polymers, 117 135, John Wiley \& Sons, USA, 1960.

26. 井上勝一郎：歯科用レジンのガラス転移点, 九州 篓科学会雑誌 $21: 238 \sim 240,1967$.
27. 井上勝一郎・林 一郎: 歯科用レシシンの 動的粘弾 性, 歯科理工学雑誌 $9: 11 \sim 14,1968$.

28. 日本化学会編: 実験化学講座 8,123 155, 丸善, 東京, 1964.

29. 井上勝一郎 : Fundamental studies on viscoelas ticity of polymethyl methacrylate polymeriz. ed by monomer-polymer technique，九州歯科 学会雑誌 $25 ： 450 \sim 452,1972$.

50. Bueche, F. : Physical properties of polymers, 254 262, John Wiley \& Sons, New York, 1962.

Table 3 Temperature Dependence of Stress Relaxation Modulus of Specimen MP-O

\begin{tabular}{|c|c|c|c|c|c|c|c|c|c|c|c|}
\hline \multirow{2}{*}{$\begin{array}{l}\text { Temp } \\
\text { Time } \\
(\mathrm{sec})\end{array}$} & \multicolumn{11}{|c|}{ Measured Stress Relaxation Modulus (dyne/chi) } \\
\hline & $37.0^{\circ} \mathrm{C}$ & $50.0^{\circ} \mathrm{C}$ & $65.5^{\circ} \mathrm{C}$ & $80.2^{\circ} \mathrm{C}$ & $89.5^{\circ} \mathrm{C}$ & $100.0^{\circ} \mathrm{C}$ & $104.5^{\circ} \mathrm{C}$ & $107.0^{\circ} \mathrm{C}$ & $110.0^{\circ} \mathrm{C}$ & $114.2^{\circ} \mathrm{C}$ & $\mathrm{C} 120.0^{\circ} \mathrm{C}$ \\
\hline 5 & $2.13 \times 10^{10}$ & $1.99 \times 10$ & $1.75 \times 10^{10}$ & $1.67 \times 10^{10}$ & $1.38 \times 10$ & $9.79 \times 10^{10}$ & $5.48 \times 10^{9}$ & 5) $2.52 \times 11^{9}$ & $8.40 \times 18^{8}$ & $1.56 \times 10^{8}$ & $0^{8} 4.64 \times 10^{7}$ \\
\hline 7 & 2.11 & 1.98 & 1.74 & 1.65 & 1.37 & 9.48 & 5.00 & 2.15 & 6.53 & 1.23 & 4.14 \\
\hline 10 & 2.10 & 1.97 & 1.73 & 1.62 & 1.35 & 9.12 & 4.51 & 1.79 & 4.93 & $9.64 \times 10$ & 03.71 \\
\hline 15 & 2.08 & 1.95 & 1.72 & 1.60 & 1.31 & 8.70 & 3.97 & 1.45 & 3.57 & 7.38 & 3.41 \\
\hline 25 & 2.05 & 1.92 & 1.69 & 1.59 & 1.29 & 8.04 & 3.30 & 1.03 & 2.29 & 5.64 & 3.09 \\
\hline 40 & 2.04 & 1.91 & 1.67 & 1.56 & 1.25 & 7.44 & 2.67 & $7.20 \times 10^{8}$ & 1.73 & 4.44 & 2.98 \\
\hline 60 & 2.03 & 1.89 & 1.64 & 1.53 & 1.22 & 6.92 & 2.12 & 5.08 & 1.23 & 4.21 & 2.80 \\
\hline 100 & 2.01 & 1.88 & 1.60 & 1.48 & 1.15 & 6.28 & 1.54 & 3.07 & $9.87 \times 10$ & 3.16 & 2.69 \\
\hline 150 & 1.99 & 1.85 & 1.57 & 1.45 & 1.11 & 5.84 & 1.15 & 2.22 & 8.27 & 3.16 & 2.52 \\
\hline 250 & 1.98 & 1.80 & 1.53 & 1.44 & 1.06 & 5.18 & $7.88 \times 10^{\circ}$ & 1.35 & 5.80 & & 2.46 \\
\hline 400 & 1.96 & 1.79 & 1.50 & 1.42 & 1.02 & 4.29 & 5.11 & $9.55 \times 10$ & 4.42 & & \\
\hline 600 & 1.94 & 1.72 & 1.48 & 1.39 & $9.56 \times 10$ & 3.63 & 3.41 & 6.04 & 4.07 & & \\
\hline 1000 & 1.93 & 1.73 & 1.45 & 1.34 & 9.12 & 2.76 & 1.63 & 5.32 & 2.84 & & \\
\hline
\end{tabular}




\begin{tabular}{|c|c|c|c|c|c|c|c|c|c|c|c|c|c|c|}
\hline \multirow{5}{*}{ 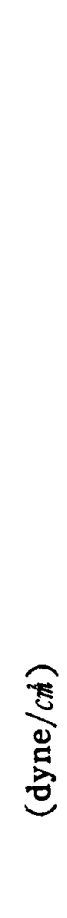 } & 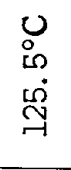 & 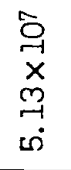 & $\begin{array}{l}尺 \\
\forall\end{array}$ & $\begin{array}{l}\stackrel{0}{N} \\
\ddot{\forall}\end{array}$ & 8 & $\begin{array}{l}R \\
\stackrel{m}{\circ}\end{array}$ & $\underset{\stackrel{\leftrightarrow}{~}}{\stackrel{\infty}{~}}$ & $\begin{array}{l}\stackrel{p}{\forall} \\
\dot{m}\end{array}$ & $\begin{array}{l}\stackrel{g}{+} \\
\dot{m}\end{array}$ & $\begin{array}{l}\text { P्ల } \\
\dot{m}\end{array}$ & $\begin{array}{l}\text { ले } \\
\text { mं }\end{array}$ & 户্ & & \\
\hline & $\begin{array}{l}0 \\
\stackrel{0}{0} \\
\dot{8} \\
\stackrel{్}{\circ}\end{array}$ & 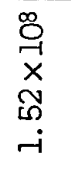 & $\underset{-i}{\stackrel{8}{\text { r }}}$ & 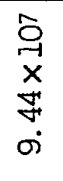 & $\begin{array}{l}\mathscr{S} \\
\stackrel{1}{r}\end{array}$ & $\underset{8}{\stackrel{8}{\sim}}$ & $\begin{array}{l}\vec{D} \\
\text { is }\end{array}$ & $\begin{array}{l}\mathscr{R} \\
\text { ம் }\end{array}$ & $\begin{array}{l}\mathscr{D} \\
\stackrel{m}{m}\end{array}$ & $\begin{array}{l}\mathscr{O} \\
\dot{m}\end{array}$ & $\begin{array}{l}\stackrel{\infty}{:} \\
\dot{m}\end{array}$ & $\underset{m}{\stackrel{\infty}{\sim}}$ & & \\
\hline & 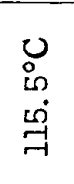 & 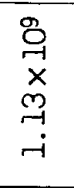 & 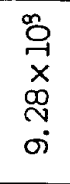 & $\stackrel{8}{\stackrel{D}{r}}$ & $\begin{array}{l}\mathscr{O} \\
\stackrel{0}{\circ}\end{array}$ & $\begin{array}{l}\mathscr{8} \\
\dot{m}\end{array}$ & $\begin{array}{l}8 \\
\stackrel{8}{i}\end{array}$ & $\begin{array}{c}8 \\
-i\end{array}$ & $\begin{array}{l}\text { ले } \\
\text { ri }\end{array}$ & $\begin{array}{l}8 \\
-i\end{array}$ & 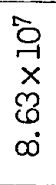 & $\begin{array}{l}\qquad 0 \\
\stackrel{6}{0}\end{array}$ & $\begin{array}{l}\infty \\
\stackrel{\infty}{0} \\
0 \\
0\end{array}$ & \\
\hline & 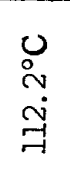 & 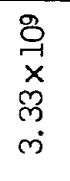 & $\begin{array}{l}\stackrel{8}{8} \\
\dot{\sim}\end{array}$ & $\begin{array}{l}\mathscr{0} \\
\dot{\sim}\end{array}$ & $\underset{\sim}{\stackrel{M}{\sim}}$ & $\begin{array}{l}\text { के } \\
\text { - }\end{array}$ & $\begin{array}{l}\vec{\forall} \\
-i\end{array}$ & $\begin{array}{l}8 \\
\stackrel{8}{-} \\
-i\end{array}$ & 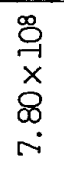 & $\begin{array}{l}\stackrel{9}{-} \\
\stackrel{6}{0}\end{array}$ & $\begin{array}{l}\text { gi } \\
\text { +i }\end{array}$ & $\begin{array}{l}\vec{m} \\
\dot{m}\end{array}$ & $\begin{array}{l}\vec{m} \\
\dot{v}\end{array}$ & \\
\hline & $\begin{array}{l}0 \\
\text { Oे } \\
\dot{0} \\
\dot{0}\end{array}$ & 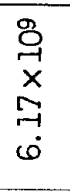 & $\begin{array}{l}\infty \\
\infty \\
\text { ம் }\end{array}$ & $\begin{array}{l}\stackrel{P}{n} \\
\dot{n}\end{array}$ & $\begin{array}{l}\text { مे } \\
\text { अ }\end{array}$ & $\underset{\sim}{N}$ & $\begin{array}{l}\stackrel{m}{\simeq} \\
\dot{m}\end{array}$ & $\begin{array}{l}\stackrel{9}{N} \\
\text { m }\end{array}$ & $\begin{array}{l}\mathscr{0} \\
\dot{\sim}\end{array}$ & $\underset{\stackrel{\sim}{\sim}}{\stackrel{7}{i}}$ & $\begin{array}{l}\oplus \\
\stackrel{-}{-}\end{array}$ & ت- & \begin{tabular}{l}
$\infty$ \\
0 \\
\hdashline \\
$\times$ \\
8 \\
8 \\
$\infty$ \\
$\infty$
\end{tabular} & $\begin{array}{l}8 \\
\dot{0}\end{array}$ \\
\hline \multirow{4}{*}{ 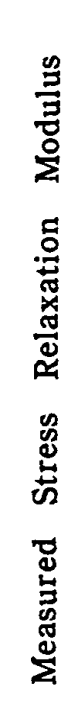 } & 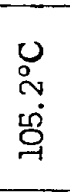 & 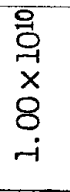 & $\begin{array}{l}\stackrel{g}{0} \\
\stackrel{7}{x} \\
\stackrel{0}{0} \\
\dot{\infty}\end{array}$ & ले & $\begin{array}{l}\mathscr{\infty} \\
\infty \\
\infty\end{array}$ & $\begin{array}{l}\stackrel{\text { ? }}{\infty} \\
\infty\end{array}$ & $\begin{array}{l}\text { Mo } \\
\text { ri }\end{array}$ & $\begin{array}{l}\text { ल } \\
\stackrel{\text { r }}{ }\end{array}$ & $\begin{array}{l}\stackrel{\infty}{:} \\
\underset{0}{0}\end{array}$ & প্ল & $\underset{\stackrel{M}{~}}{\stackrel{M}{0}}$ & $\begin{array}{l}8 \\
\text { ம் }\end{array}$ & $\begin{array}{l}\mathscr{O} \\
\stackrel{+}{+}\end{array}$ & $\begin{array}{l}\mathscr{8} \\
\infty \\
\infty\end{array}$ \\
\hline & $\begin{array}{l}0 \\
0 \\
8 \\
8\end{array}$ & 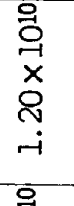 & $\begin{array}{l}\underset{-}{-} \\
-i\end{array}$ & $\underset{-}{\stackrel{H}{-}}$ & $\begin{array}{l}-7 \\
-i\end{array}$ & $\stackrel{5}{\circ}$ & $\begin{array}{l}\stackrel{\circ}{\circ} \\
\stackrel{-}{-}\end{array}$ & $\begin{array}{c}80 \\
\text { Oi }\end{array}$ & $\begin{array}{l}\stackrel{9}{0} \\
\stackrel{1}{x} \\
\vec{\sigma} \\
\dot{\sigma}\end{array}$ & $\begin{array}{l}\mathscr{\infty} \\
\infty \\
\infty\end{array}$ & $\begin{array}{l}\stackrel{0}{0} \\
\stackrel{2}{\circ}\end{array}$ & $\underset{\rightarrow}{\stackrel{9}{r}}$ & $\begin{array}{l}\mathscr{O} \\
\text { in }\end{array}$ & $\begin{array}{l}\vec{m} \\
\dot{\omega}\end{array}$ \\
\hline & $\begin{array}{l}0 \\
0 \\
\dot{8}\end{array}$ & $\begin{array}{l}\stackrel{0}{0} \\
\times \\
\times \\
\rightarrow \\
- \\
-\end{array}$ & $\underset{-i}{\text { P }}$ & 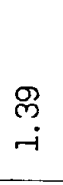 & $\stackrel{\text { ले }}{\text { न्- }}$ & $\stackrel{\text { mे }}{-}$ & $\underset{\text { P. }}{\stackrel{M}{-1}}$ & $\begin{array}{c}\text { ले } \\
\text { नi }\end{array}$ & $\underset{-i}{\stackrel{\infty}{\sim}}$ & 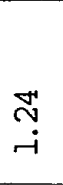 & $\begin{array}{l}\underset{\sim}{\infty} \\
\rightarrow \\
-\end{array}$ & $\begin{array}{l}\text { Э } \\
\text { - }\end{array}$ & $\stackrel{\text { ஜூ }}{\text { - }}$ & 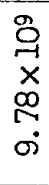 \\
\hline & $\begin{array}{l}0 \\
\stackrel{\circ}{0} \\
\dot{8}\end{array}$ & $\begin{array}{l}0 \\
0 \\
-1 \\
\times \\
0 \\
0 \\
\stackrel{-}{-} \\
\end{array}$ & $\begin{array}{l}\hat{6} \\
-i\end{array}$ & $\begin{array}{l}\mathscr{0} \\
\stackrel{-}{-}\end{array}$ & $\begin{array}{l}\overrightarrow{0} \\
-i\end{array}$ & $\begin{array}{c}\mathscr{8} \\
-i\end{array}$ & $\begin{array}{l}8 \\
\stackrel{8}{-1}\end{array}$ & $\begin{array}{l}\infty \\
\underset{⿴ 囗}{\circledR} \\
-i\end{array}$ & 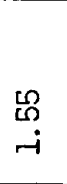 & $\begin{array}{l}\stackrel{\nabla}{0} \\
\stackrel{-}{-1}\end{array}$ & $\begin{array}{l}8 \\
-i\end{array}$ & $\begin{array}{l}f \\
-i\end{array}$ & $\underset{\stackrel{\mathscr{H}}{\text { i }}}{ }$ & $\begin{array}{c}\infty \\
\stackrel{m}{-}\end{array}$ \\
\hline & $\begin{array}{l}0 \\
0 \\
0 \\
0 \\
0\end{array}$ & 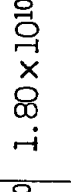 & $\begin{array}{l}\stackrel{\infty}{\sim} \\
\underset{-i}{-1}\end{array}$ & $\underset{\Im}{-i}$ & 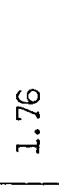 & $\underset{\sim}{\stackrel{m}{T}}$ & $\stackrel{-}{-i}$ & 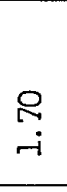 & $\begin{array}{l}\infty \\
\vdots \\
-i\end{array}$ & $\begin{array}{l}\mathscr{\Theta} \\
\Theta \\
-i\end{array}$ & $\begin{array}{l}\mathscr{0} \\
0 \\
-i\end{array}$ & $\begin{array}{l}\widetilde{6} \\
-i\end{array}$ & 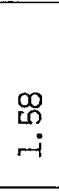 & 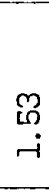 \\
\hline & $\begin{array}{l}0 \\
\stackrel{\circ}{\circ} \\
0\end{array}$ & 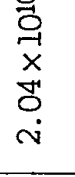 & $\begin{array}{l}\ddot{O} \\
\stackrel{i}{*}\end{array}$ & $\begin{array}{l}\tilde{O} \\
\stackrel{\sim}{\sim}\end{array}$ & $\begin{array}{l}\overrightarrow{0} \\
\dot{\sim}\end{array}$ & $\begin{array}{l}8 \\
\stackrel{-1}{-1}\end{array}$ & $\begin{array}{l}\hat{\sigma} \\
\text { ґ् }\end{array}$ & $\begin{array}{l}\stackrel{H}{\circ} \\
-i\end{array}$ & $\begin{array}{l}\mathscr{8} \\
\stackrel{-}{-1}\end{array}$ & $\begin{array}{l}\text { ऊे } \\
\text {-i }\end{array}$ & $\begin{array}{l}\infty \\
\stackrel{\infty}{-i} \\
-i\end{array}$ & $\begin{array}{c}\infty \\
-i \\
-i\end{array}$ & $\begin{array}{l}\stackrel{\Xi}{\infty} \\
-i\end{array}$ & $\begin{array}{l}\infty \\
-i \\
-i\end{array}$ \\
\hline & $\begin{array}{l}0 \\
\text { : } \\
\text { ले }\end{array}$ & 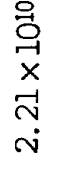 & $\begin{array}{l}\stackrel{9}{-} \\
\stackrel{i}{i}\end{array}$ & $\begin{array}{l}\text { ने } \\
\stackrel{i}{i}\end{array}$ & $\begin{array}{l}\stackrel{0}{\sim} \\
\stackrel{\sim}{\sim}\end{array}$ & $\begin{array}{l}\stackrel{M}{\sim} \\
\stackrel{\sim}{r}\end{array}$ & $\begin{array}{l}\overrightarrow{7} \\
\stackrel{i}{\sim}\end{array}$ & $\begin{array}{l}\stackrel{\infty}{\circ} \\
\stackrel{\sim}{\sim}\end{array}$ & $\begin{array}{l}\stackrel{8}{o} \\
\dot{N}\end{array}$ & $\begin{array}{l}\text { ஜ̊ } \\
\stackrel{\sim}{\sim}\end{array}$ & $\begin{array}{l}\mathscr{O} \\
\dot{\sim}\end{array}$ & $\begin{array}{l}\tilde{O} \\
\dot{\sim}\end{array}$ & $\begin{array}{l}8 \\
\dot{i}\end{array}$ & 今ે \\
\hline & \&̊요 & م & $N$ & 어 & $\stackrel{\mathscr{H}}{\circ}$ & $\stackrel{\mathscr{N}}{\mathrm{N}}$ & F & 8 & $\underset{r=1}{8}$ & 号 & 怘 & 8 & 8 & 8 \\
\hline
\end{tabular}


Table 5 Temperature Dependence of Stress Relaxation Modulus of unsoaked Specimen

\begin{tabular}{|c|c|c|c|c|c|}
\hline \multicolumn{2}{|c|}{$\mathrm{PP}-\mathrm{O}$} & \multicolumn{2}{|c|}{$\mathrm{MP}-\mathrm{O}$} & \multicolumn{2}{|c|}{$M M-O$} \\
\hline Temp $\left({ }^{\circ} \mathrm{C}\right)$ & $\begin{array}{c}\operatorname{Er}(10) \\
\left(\text { dyne } / \mathrm{cm}^{2}\right)\end{array}$ & Temp $\left({ }^{\circ} \mathrm{C}\right)$ & $\begin{array}{c}\operatorname{Er}(10) \\
\left(\text { dyne } / \mathrm{cm}^{2}\right)\end{array}$ & Temp $\left({ }^{\circ} \mathrm{C}\right)$ & $\begin{array}{c}\operatorname{Er}(10) \\
\left(\text { dyne } / \mathrm{cm}^{2}\right)\end{array}$ \\
\hline 37.0 & $1.73 \times 1010$ & 37.0 & $2.10 \times 1010$ & 37.0 & $2.17 \times 10_{10}$ \\
\hline 45.0 & 1.66 & 44.5 & 2.03 & 40.5 & 2.09 \\
\hline 50.3 & 1.57 & 50.0 & 1.97 & 50.5 & 2.02 \\
\hline 55.5 & 1.43 & 60.0 & 1.83 & 56.3 & 1.91 \\
\hline 61.7 & 1.37 & 65.5 & 1.73 & 60.0 & 1.89 \\
\hline 65.2 & 1.29 & 70.0 & 1.70 & 65.0 & 1.77 \\
\hline 70.0 & 1.19 & 75.2 & 1.63 & 75.5 & 1.75 \\
\hline 74.0 & 1.04 & 85.0 & 1.50 & 80.2 & 1.66 \\
\hline 77.0 & $8.91 \times 109$ & 89.5 & 1.35 & 85.0 & 1.53 \\
\hline 79.0 & 7.68 & 95.0 & 1.16 & 90.0 & 1.39 \\
\hline 82.0 & 5.21 & 100.0 & $9.12 \times 109$ & 95.0 & 1.29 \\
\hline 84.0 & 3.91 & 102.0 & 8.09 & 100.0 & 1.14 \\
\hline 86.0 & 2.33 & 104.5 & 4.51 & 105.0 & $9.37 \times 109$ \\
\hline 88.0 & 1.34 & 107.0 & 1.79 & 110.0 & 5.4 \\
\hline 91.0 & $8.27 \times 108$ & 210.0 & $4.93 \times 108$ & 112.0 & 2.66 \\
\hline 93.0 & 6.10 & 112.3 & 2.21 & 115.5 & $7.20 \times 108$ \\
\hline 95.1 & 3.60 & 114.2 & $9.64 \times 10^{7}$ & 120.5 & $9.44 \times 107$ \\
\hline 97.0 & 2.46 & 116.0 & 6.80 & 125.5 & 4.26 \\
\hline 100.0 & 1.40 & 117.0 & 5.31 & & \\
\hline $1_{03.9}$ & $8.42 \times 107$ & 118.0 & 4.36 & & \\
\hline$I_{08.0}$ & 4.62 & 120.0 & 3.71 & & \\
\hline$l_{20.5}$ & 1.88 & & & & \\
\hline
\end{tabular}

Table 6 Temperature Dependence of Stress Relaxation Modulus of Specimen soaked in Acetone

\begin{tabular}{|c|c|c|c|c|c|}
\hline \multicolumn{2}{|c|}{$P P-A$} & \multicolumn{2}{|c|}{$\mathrm{MP}-\mathrm{A}$} & \multicolumn{2}{|c|}{$\mathrm{MM}-\mathrm{A}$} \\
\hline Temp $\left({ }^{\circ} \mathrm{C}\right)$ & $\begin{array}{c}\operatorname{Er}(10) \\
\left(\text { dyne } / \mathrm{cm}^{2}\right)\end{array}$ & Temp $\left({ }^{\circ} \mathrm{C}\right)$ & $\begin{array}{c}\operatorname{Er}(10) \\
\left(\text { dyne } / \mathrm{cm}^{2}\right)\end{array}$ & Temp $\left({ }^{\circ} \mathrm{C}\right)$ & $\begin{array}{c}\operatorname{Er}(10) \\
\left(\text { dyne } / \mathrm{cm}^{2}\right)\end{array}$ \\
\hline 37.0 & $1.71 \times 10^{10}$ & 37.0 & $1.95 \times 10^{10}$ & 37.0 & $1.81 \times 1010$ \\
\hline 43.5 & 1.55 & 44.5 & 1.87 & 46.0 & 1.76 \\
\hline
\end{tabular}




\begin{tabular}{|l|l|l|l|l|l|}
55.5 & 1.40 & 50.0 & 1.76 & 50.0 & 1.66 \\
60.0 & 1.32 & 56.0 & 1.66 & 55.0 & 1.55 \\
65.0 & 1.23 & 61.0 & 1.60 & 60.0 & 1.51 \\
74.6 & 1.05 & 66.0 & 1.55 & 70.0 & 1.49 \\
80.5 & $7.60 \times 10^{9}$ & 10.3 & 1.49 & 80.0 & 1.37 \\
84.5 & 5.35 & 74.5 & 1.45 & 85.0 & 1.30 \\
90.0 & 2.03 & 80.1 & 1.37 & 90.0 & 1.23 \\
95.0 & $6.08 \times 10^{2}$ & 84.5 & 1.27 & 94.0 & 1.12 \\
100.0 & 2.30 & 90.0 & 1.15 & 100.0 & 1.02 \\
105.0 & 9.74 & 94.3 & 1.04 & 105.0 & $7.73 \times 109$ \\
115.0 & $3.64 \times 10^{2}$ & 100.0 & $1.17 \times 10^{9}$ & 110.0 & 4.45 \\
120.0 & 1.83 & 104.0 & 4.21 & 115.0 & $7.40 \times 10^{3}$ \\
& & 107.5 & 1.27 & 120.0 & 1.04 \\
& & 110.5 & $3.16 \times 10^{8}$ & 125.0 & $4.81 \times 10^{2}$ \\
& & 115.0 & $8.46 \times 10^{7}$ & & \\
\hline
\end{tabular}

Table 7 Temperature Dependence of Stress Relaxation Modulus of Specimen soaked in Benzene

\begin{tabular}{|c|c|c|c|c|c|}
\hline \multicolumn{2}{|c|}{$\mathrm{PP}-\mathrm{B}$} & \multicolumn{2}{|c|}{$\mathrm{MP}-\mathrm{B}$} & \multicolumn{2}{|c|}{$M M-B$} \\
\hline Temp $\left({ }^{\circ} \mathrm{C}\right)$ & $\underset{\left(\text { dyne } / \mathrm{cm}^{2}\right)}{\operatorname{Er}(10)}$ & Temp $\left({ }^{\circ} \mathrm{C}\right)$ & $\begin{array}{c}\operatorname{Er}(10) \\
(\text { dyne/cm²) }\end{array}$ & Temp $\left({ }^{\circ} \mathrm{C}\right)$ & 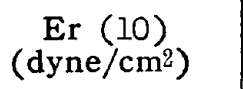 \\
\hline 37.0 & $1.73 \times 1010$ & 37.0 & $1.74 \times 1010$ & 37.8 & $2.01 \times 1010$ \\
\hline 40.5 & 1.65 & 44.0 & 1.71 & 40.0 & 1.91 \\
\hline 50.0 & 1.51 & 55.2 & 1.59 & 47.5 & 1.85 \\
\hline 56.0 & 1.46 & 70.1 & 1.47 & 55.0 & 1.73 \\
\hline 61.0 & 1.31 & 75.0 & 1.37 & 70.0 & 1.70 \\
\hline 65.5 & 1.23 & 80.2 & 1.29 & 80.0 & 1.51 \\
\hline 70.5 & 1.09 & 85.0 & 1.19 & 90.0 & 1.32 \\
\hline 75.0 & $9.74 \times 10^{9}$ & 90.0 & 1.08 & 95.0 & 1.23 \\
\hline 80.5 & 5.50 & 95.0 & $9.81 \times 109$ & 100.0 & 1.10 \\
\hline 86.0 & 1.84 & 100.0 & 8.08 & 105.0 & $9.87 \times 10^{3}$ \\
\hline 90.0 & $6.08 \times 108$ & 103.5 & 4.78 & 110.0 & 4.75 \\
\hline 95.0 & 2.93 & 107.8 & 1.17 & 115.0 & $6.26 \times 10^{3}$ \\
\hline 101.0 & $9.64 \times 10^{7}$ & 111.0 & $2.40 \times 10^{8}$ & 116.0 & 6.41 \\
\hline
\end{tabular}




\begin{tabular}{|l|l|l|l|l|l|}
115.0 & 2.46 & 115.0 & $6.21 \times 10^{7}$ & 120.0 & 1.28 \\
120.0 & 1.70 & 117.0 & 4.53 & 125.0 & $5.39 \times 10^{7}$ \\
& & 120.0 & 3.38 & & \\
\hline
\end{tabular}

Table 8 Temperature Dependence of Stress Relaxation Modulus of Specimen soaked in Xylene

\begin{tabular}{|c|c|c|c|c|c|}
\hline \multicolumn{2}{|c|}{$P P-X$} & \multicolumn{2}{|c|}{$M P-X$} & \multicolumn{2}{|c|}{$M M-X$} \\
\hline Temp $\left({ }^{\circ} \mathrm{C}\right)$ & $\begin{array}{c}\operatorname{Er}(10) \\
\left(\text { dyne } / \mathrm{cm}^{2}\right)\end{array}$ & Temp $\left({ }^{\circ} \mathrm{C}\right)$ & $\begin{array}{c}\text { Er }(10) \\
\left(\text { dyne } / \mathrm{cm}^{2}\right)\end{array}$ & Temp $\left({ }^{\circ} \mathrm{C}\right)$ & $\begin{array}{c}\operatorname{Er}(10) \\
\left(\text { dyne } / \mathrm{cm}^{2}\right)\end{array}$ \\
\hline 37.0 & $1.92 \times 1010$ & 37.0 & $2.06 \times 1010$ & 37.0 & $2.19 \times 1010$ \\
\hline 50.5 & 1.72 & 45.0 & 1.99 & 45.0 & 1.94 \\
\hline 55.8 & 1.61 & 50.0 & 1.94 & 50.0 & 1.91 \\
\hline 59.5 & 1.52 & 55.0 & 1.82 & 55.0 & 1.86 \\
\hline 64.5 & 1.43 & 60.0 & 1.77 & 60.0 & 1.79 \\
\hline 70.0 & 1.33 & 65.0 & 1.74 & 65.0 & 1.72 \\
\hline 75.0 & 1.07 & 70.0 & 1.66 & 75.0 & 1.60 \\
\hline 80.0 & $6.91 \times 10^{9}$ & 75.0 & 1.53 & 80.0 & 1.51 \\
\hline 85.0 & 2.88 & 80.0 & 1.51 & 85.0 & 1.45 \\
\hline 90.0 & $8.51 \times 10^{8}$ & 85.0 & 1.41 & 90.0 & 1.32 \\
\hline 94.5 & 4.62 & 89.2 & 1.27 & 94.0 & 1.30 \\
\hline 100.0 & 1.35 & 94.5 & 1.09 & 100.0 & 1.19 \\
\hline 105.0 & $6.57 \times 10^{7}$ & 100.0 & $8.72 \times 109$ & 104.5 & $9.68 \times 10^{9}$ \\
\hline 109.8 & 4.01 & 104.0 & 4.66 & 110.5 & 5.59 \\
\hline 120.0 & 1.84 & 107.0 & 1.71 & 116.0 & $8.28 \times 10^{8}$ \\
\hline & & 110.0 & $5.08 \times 10^{8}$ & 121.0 & 1.15 \\
\hline & & 115.0 & $8.10 \times 10^{7}$ & 125.0 & $5.28 \times 107$ \\
\hline & & 120.5 & 3.37 & & \\
\hline
\end{tabular}

Table 9 Temperature Dependence of Stress Relaxation Modulus of Specimen soaked in Chloroform

\begin{tabular}{|c|c|c|c|c|c|}
\hline \multicolumn{2}{|c|}{$\mathrm{PP}-\mathrm{C}$} & \multicolumn{2}{|c|}{$\mathrm{MP}-\mathrm{C}$} & \multicolumn{2}{|c|}{ MM-C } \\
\hline Temp $\left({ }^{\circ} \mathrm{C}\right)$ & $\begin{array}{c}\operatorname{Er}(10) \\
\left(\text { dyne }^{2} \mathrm{~cm}^{2}\right)\end{array}$ & Temp $\left({ }^{\circ} \mathrm{C}\right)$ & $\begin{array}{c}\operatorname{Er}(10) \\
(\text { dyne/cm²) }\end{array}$ & Temp $\left({ }^{\circ} \mathrm{C}\right)$ & $\begin{array}{c}\operatorname{Er}(10) \\
\left(\text { dyne } / \mathrm{cm}^{2}\right)\end{array}$ \\
\hline 37.0 & $1.56 \times 10^{17}$ & 37.0 & $1.84 \times 10^{10}$ & 37.0 & $2.16 \times 1010$ \\
\hline 50.0 & 1.32 & 46.0 & 1.68 & 48.0 & 2.00 \\
\hline
\end{tabular}




\begin{tabular}{|c|c|c|c|c|c|}
\hline 55.5 & 1.20 & 50.0 & 1.66 & 61.0 & 1.87 \\
\hline 60.2 & 1.07 & 55.8 & 1.52 & 70.0 & 1.76 \\
\hline 65.0 & $8.92 \times 10^{9}$ & 60.0 & 1.47 & 75.5 & 1.66 \\
\hline 70.6 & 5.72 & 65.0 & 1.39 & 80.0 & 1.59 \\
\hline 74.5 & 3.26 & 70.0 & 1.33 & 85.0 & 1.47 \\
\hline 78.0 & 1.70 & 75.0 & 1.25 & 90.0 & 1.30 \\
\hline 82.0 & $8.28 \times 10^{8}$ & 80.0 & 1.04 & 95.8 & 1.09 \\
\hline 89.6 & 3.58 & 85.0 & $9.39 \times 10^{9}$ & 100.0 & $9.12 \times 10^{9}$ \\
\hline 94.5 & 1.94 & 90.0 & 6.44 & 105.0 & 5.97 \\
\hline 100.0 & $9.57 \times 10^{7}$ & 95.0 & 4.10 & 109.0 & 3.86 \\
\hline 110.0 & 3.34 & 100.0 & 2.16 & 115.0 & $5.90 \times 10^{9}$ \\
\hline \multirow[t]{6}{*}{114.5} & 2.10 & 103.8 & $8.61 \times 10^{8}$ & 120.0 & $8.27 \times 10^{9}$ \\
\hline & & 106.0 & 5.48 & 125.0 & 3.40 \\
\hline & & 107.0 & 3.19 & & \\
\hline & & 110.0 & 1.43 & & \\
\hline & & 115.0 & $5.46 \times 10^{7}$ & & \\
\hline & & 120.0 & 2.64 & & \\
\hline
\end{tabular}

Table 10 Temperature Dependence of Stress Relaxation Modulus of Specimen soaked ih Eugenol

\begin{tabular}{|c|c|c|c|c|c|}
\hline \multicolumn{2}{|c|}{$\mathbf{P P}-\mathbf{E u}$} & \multicolumn{2}{|c|}{$\mathrm{MP}-\mathrm{Eu}$} & \multicolumn{2}{|c|}{$\mathbf{M M}-\mathbf{E u}$} \\
\hline Temp $\left({ }^{\circ} \mathrm{C}\right)$ & $\underset{(\text { dyne/cm }}{\operatorname{Er}(10)}$ & $\operatorname{Temp}\left({ }^{\circ} \mathrm{C}\right)$ & $\begin{array}{c}\operatorname{Er}(10) \\
(\text { dyne/cm²) }\end{array}$ & $\operatorname{Temp}\left({ }^{\circ} \mathrm{C}\right)$ & $\frac{\operatorname{Er}(10)}{\left(\text { dyne } / \mathrm{cm}^{2}\right)}$ \\
\hline 37.0 & $1.73 \times 10^{10}$ & 37.0 & $2.14 \times 10^{10}$ & 37.0 & $2.17 \times 10^{10}$ \\
\hline 40.8 & 1.71 & 43.5 & 2.10 & 45.5 & 2.02 \\
\hline 45.8 & 1.62 & 50.3 & 2.01 & 50.0 & 1.94 \\
\hline 50.0 & 1.54 & 55.0 & $2 . \infty$ & 60.0 & 1.82 \\
\hline 55.5 & 1.45 & 60.0 & 1.90 & 65.0 & 1.78 \\
\hline 60.7 & 1.36 & 64.5 & 1.81 & 70.0 & 1.72 \\
\hline 65.7 & 1.21 & 70.0 & 1.71 & 75.0 & 1.67 \\
\hline 70.0 & 1.19 & 75.0 & 1.63 & 80.0 & 1.51 \\
\hline 73.0 & 1.07 & 80.0 & 1.52 & 85.0 & 1.47 \\
\hline 77.0 & $7.72 \times 10^{9}$ & 84.5 & 1.40 & 90.0 & 1.30 \\
\hline 80.0 & 5.46 & 89.8 & 1.28 & 95.0 & 1.29 \\
\hline 83.2 & 3.14 & 94.5 & 1.11 & 100.0 & 1.13 \\
\hline
\end{tabular}




\begin{tabular}{|l|l|l|l|l|l|}
86.0 & 12.15 & 100.0 & $8.85 \times 10^{9}$ & 105.0 & $8.89 \times 109$ \\
90.0 & 1.00 & 103.5 & 6.49 & 110.0 & 5.71 \\
94.5 & $3.35 \times 10^{8}$ & 107.0 & 2.41 & 115.0 & 1.26 \\
100.0 & 1.20 & 110.0 & $6.99 \times 10^{8}$ & 120.0 & $1.26 \times 10^{8}$ \\
105.0 & $5.27 \times 10^{7}$ & 113.7 & 1.60 & 125.0 & $4.32 \times 10^{7}$ \\
110.0 & 4.06 & 115.6 & $8.50 \times 10^{7}$ & & \\
115.0 & 2.33 & 120.5 & 3.77 & & \\
\hline
\end{tabular}

Table 11 Temperature Dependence of Stress Relaxation Modulus of Specimen soaked in Ethyl Alcohol

\begin{tabular}{|c|c|c|c|c|c|}
\hline \multicolumn{2}{|c|}{$\mathrm{PP}-\mathrm{Et}$} & \multicolumn{2}{|c|}{$\mathrm{MP}-\mathrm{Et}$} & \multicolumn{2}{|c|}{$M M-E t$} \\
\hline Temp $\left({ }^{\circ} \mathrm{C}\right)$ & $\begin{array}{c}\operatorname{Er}(10) \\
(\text { dyne/cm²) }\end{array}$ & Temp $\left({ }^{\circ} \mathrm{C}\right)$ & $\begin{array}{l}\operatorname{Er}(10) \\
(\text { dyne/cm²) }\end{array}$ & Temp $\left({ }^{\circ} \mathrm{C}\right)$ & $\begin{array}{c}\operatorname{Er}(10) \\
\left(\text { dyne } / \mathrm{cm}^{2}\right)\end{array}$ \\
\hline 37.0 & $1.79 \times 10^{10}$ & 37.0 & $2.16 \times 1010$ & 37.0 & $2.24 \times 10^{10}$ \\
\hline 46.0 & 1.72 & 45.0 & 2.06 & 41.0 & 2.07 \\
\hline 50.0 & 1.70 & 50.0 & 2.02 & 47.0 & 2.03 \\
\hline 61.0 & 1.62 & 60.0 & 1.96 & 56.0 & 2.00 \\
\hline 65.0 & 1.55 & 70.2 & 1.87 & 60.0 & 1.81 \\
\hline 70.0 & 1.48 & 75.8 & 1.72 & 69.8 & 1.76 \\
\hline 75.8 & 1.41 & 80.0 & 1.65 & 80.0 & 1.60 \\
\hline 80.0 & 1.37 & 85.0 & 1.55 & 84.8 & 1.50 \\
\hline 85.2 & 1.26 & 90.0 & 1.42 & 89.0 & 1.47 \\
\hline 90.0 & 1.14 & 94.5 & 1.33 & 95.0 & 1.29 \\
\hline 94.5 & $8.22 \times 109$ & 100.0 & 1.08 & 100.0 & 1.08 \\
\hline 100.0 & 5.40 & 104.0 & $6.70 \times 109$ & 104.5 & $7.80 \times 103$ \\
\hline 104.5 & 3.56 & 106.0 & 4.00 & 110.5 & 4.00 \\
\hline 110.0 & 2.53 & 111.5 & 1.22 & 116.0 & 2.61 \\
\hline 115.5 & 1.04 & 115.0 & $7.76 \times 108$ & 120.5 & $6.72 \times 103$ \\
\hline 120.3 & $2.08 \times 108$ & 117.0 & 5.75 & 125.9 & $7.27 \times 107$ \\
\hline 124.5 & $4.49 \times 10^{7}$ & 120.0 & 2.52 & & \\
\hline & & 123.0 & $7.02 \times 107$ & & \\
\hline & & 125.0 & 4.22 & & \\
\hline
\end{tabular}


Table 12 Temperature Dependence of Stress Relaxation Modulus of Specimen soaked in Water

\begin{tabular}{|c|c|c|c|c|c|}
\hline \multicolumn{2}{|c|}{$\mathrm{PP}-\mathrm{W}$} & \multicolumn{2}{|c|}{$M P-W$} & \multicolumn{2}{|c|}{$M M-W$} \\
\hline Temp $\left({ }^{\circ} \mathrm{C}\right)$ & $\begin{array}{c}\operatorname{Er}(10) \\
\left(\text { dyne } / \mathrm{cm}^{2}\right)\end{array}$ & Temp $\left({ }^{\circ} \mathrm{C}\right)$ & $\begin{array}{c}\operatorname{Er}(10) \\
(\text { dyne/cm²) }\end{array}$ & Temp $\left({ }^{\circ} \mathrm{C}\right)$ & $\begin{array}{c}\operatorname{Er}(10) \\
\left(\text { dyne } / \mathrm{cm}^{2}\right)\end{array}$ \\
\hline 37.8 & $1.71 \times 10^{10}$ & 37.0 & $2.04 \times 10^{10}$ & 37.0 & $2.09 \times 10^{10}$ \\
\hline 40.0 & 1.62 & 48.2 & 1.87 & 44.0 & $1.99^{\cdots}$ \\
\hline 55.8 & 1.44 & 52.0 & 1.84 & 56.0 & 1.77 \\
\hline 60.0 & 1.37 & 58.2 & 1.75 & 65.0 & 1.75 \\
\hline 65.5 & 1.29 & 65.5 & 1.66 & 70.0 & 1.60 \\
\hline 70.5 & 1.20 & 74.2 & 1.53 & 75.0 & 1.58 \\
\hline 74.5 & 1.12 & 80.0 & 1.45 & 80.0 & 1.53 \\
\hline 80.0 & $8.23 \times 10^{9}$ & 85.1 & 1.34 & 85.0 & 1.39 \\
\hline 85.0 & 4.00 & 90.1 & 1.27 & 90.0 & 1.36 \\
\hline 89.0 & 1.60 & 94.5 & 1.17 & 94.5 & 1.28 \\
\hline 95.0 & $5.59 \times 10^{3}$ & 100.0 & $8.77 \times 10^{9}$ & 100.0 & 1.09 \\
\hline 100.0 & 2.08 & 104.0 & 4.81 & 105.8 & $8.49 \times 10^{9}$ \\
\hline 105.5 & $6.01 \times 10^{7}$ & 105.0 & 4.00 & 110.3 & 4.59 \\
\hline \multirow[t]{5}{*}{115.0} & 2.38 & 108.0 & 1.14 & 114.0 & 1.20 \\
\hline & & 110.0 & $4.75 \times 10^{3}$ & 116.0 & $6.45 \times 108$ \\
\hline & & 112.1 & 2.07 & 118.5 & 1.66 \\
\hline & . & 115.7 & $7.53 \times 107$ & 122.5 & $5.82 \times 10^{7}$ \\
\hline & & & 3.64 & 125.0 & 4.02 \\
\hline
\end{tabular}

Table 13 Stress Relaxation Modulus of Specimen PP:soaked in various Solvents

\begin{tabular}{|c|l|l|l|l|l|l|l|l|}
\hline Time(sec) & Air & Acetone & Benzene & Xylene & $\begin{array}{c}\text { Chloro- } \\
\text { form }\end{array}$ & Eugenol & $\begin{array}{c}\text { Ethyl } \\
\text { alcohol }\end{array}$ & Water \\
\hline 10 & $1.83 \times 1010$ & $1.81 \times 1010$ & $1.82 \times 1010$ & $2.00 \times 1010$ & $1.67 \times 1010$ & $1.83 \times 1010$ & $1.88 \times 1010$ & $1.81 \times 1010$ \\
101 & 1.73 & 1.71 & 1.72 & 1.92 & 1.56 & 1.73 & 1.79 & 1.71 \\
102 & 1.62 & 1.61 & 1.62 & 1.84 & 1.46 & 1.64 & 1.72 & 1.61 \\
$10^{3}$ & 1.53 & 1.52 & 1.52 & 1.75 & 1.34 & 1.54 & 1.66 & 1.51 \\
105 & 1.40 & 1.42 & 1.43 & 1.66 & 1.23 & 1.44 & 1.58 & 1.41 \\
$10^{5}$ & 1.32 & 1.32 & 1.33 & 1.50 & 1.13 & 1.34 & 1.48 & 1.32 \\
105 & 1.22 & 1.21 & 1.24 & 1.40 & 1.00 & 1.23 & 1.40 & 1.22 \\
\hline
\end{tabular}




\begin{tabular}{|c|c|c|c|c|c|c|c|c|}
\hline 107 & 1.15 & 1.12 & 1.14 & 1.27 & $8.00 \times 10^{9}$ & 1.13 & 1.31 & 1.13 \\
\hline $10^{8}$ & 1.03 & 1.01 & 1.04 & 1.10 & 5.75 & 1.08 & 1.20 & 1.01 \\
\hline $10^{9}$ & $9.00 \times 10^{9}$ & $8.30 \times 10^{9}$ & $9.00 \times 10^{9}$ & $9.50 \times 109$ & 3.20 & $8.50 \times 10^{9}$ & 1. 12 & $8.50 \times 10^{3}$ \\
\hline 1010 & 6.90 & 5.70 & 7.10 & 7.30 & 1.65 & 6.10 & $9.80 \times 10^{9}$ & 5.75 \\
\hline 1011 & 4.30 & 3.10 & 4.10 & 4.00 & $8.10 \times 10^{8}$ & 5.30 & 8.40 & 1.10 \\
\hline 1012 & 1.95 & 1.55 & 1.69 & 1.72 & 4.10 & 1.65 & 6.40 & 1.41 \\
\hline 1013 & $7.20 \times 10^{8}$ & $7.50 \times 10^{8}$ & $6.40 \times 108$ & $6.90 \times 108$ & 2.05 & $7.70 \times 109$ & 4.70 & $6.10 \times 10^{3}$ \\
\hline 1014 & 2.95 & 3.70 & 2.45 & 2.50 & 1.10 & 3.70 & 3.30 & 2.63 \\
\hline 1015 & 1.37 & 1.75 & 1.03 & $9.20 \times 107$ & $6.00 \times 10^{7}$ & 1.65 & 2.15 & $1 . \infty 0$ \\
\hline 1016 & $6.10 \times 10^{7}$ & $7.80 \times 10^{7}$ & $5.30 \times 107$ & 4.10 & 2.85 & $6.90 \times 10^{7}$ & 1.30 & $4.20 \times 10^{7}$ \\
\hline 1017 & 2.85 & 3.80 & 3.25 & 2.26 & 1.47 & 3.00 & $6.90 \times 10^{8}$ & 2.70 \\
\hline 1018 & 1.54 & & & & & & 2.80 & \\
\hline 1019 & & & & & & & $7.40 \times 10^{7}$ & \\
\hline 1020 & & & & & & & 2.45 & \\
\hline
\end{tabular}

Table 14 Stress Relaxation Modulus of Specimen MP soaked in various Solvents

\begin{tabular}{|c|c|c|c|c|c|c|c|c|}
\hline \begin{tabular}{|r|} 
Solvent \\
Time $(\mathrm{sec})$ \\
\end{tabular} & Air & Acetone & Benzene & Xylene & $\begin{array}{l}\text { Chloro- } \\
\text { form }\end{array}$ & Eugenol & $\begin{array}{l}\text { Ethyl } \\
\text { alcohol }\end{array}$ & Water \\
\hline $10^{3}$ & $2.20 \times 10^{10}$ & $2.05 \times 10^{10}$ & $1.82 \times 1010$ & $2.26 \times 1010$ & $1.89 \times 10^{10}$ & $2.24 \times 1010$ & $2.12 \times 1010$ & $2.14 \times 10^{10}$ \\
\hline 101 & 2.10 & 1.95 & 1.73 & 2.16 & 1.79 & 2.14 & 2.02 & 2.04 \\
\hline $10^{2}$ & 2.01 & 1.85 & 1.67 & 2.06 & 1.70 & 2.04 & 1.90 & 1.94 \\
\hline 103 & 1.92 & 1.75 & 1.57 & 1.97 & 1.60 & 1.94 & 1.80 & 1.84 \\
\hline $10^{4}$ & 1.82 & 1.66 & 1.49 & 1.85 & 1.50 & 1.83 & 1.69 & 1.74 \\
\hline 105 & 1.72 & 1.57 & 1.39 & 1.75 & 1.40 & 1.74 & 1.58 & 1.64 \\
\hline $10^{5}$ & 1.62 & 1.49 & 1.30 & 1.64 & 1.30 & 1.64 & 1.48 & 1.55 \\
\hline 107 & 1.52 & 1.38 & 1.22 & 1.54 & 1.20 & 1.54 & 1.39 & 1.45 \\
\hline $10^{8}$ & 1.42 & 1.24 & 1.12 & 1.45 & 1.10 & 1.44 & 1.31 & 1.34 \\
\hline 109 & 1.32 & 1.14 & 1.00 & 1.35 & $9.90 \times 10^{9}$ & 1.34 & 1.20 & 1.24 \\
\hline 1010 & 1.22 & 1.04 & $9.00 \times 109$ & 1.22 & 8.00 & 1.23 & 1.10 & 1.12 \\
\hline 1011 & 1.10 & $9.10 \times 10^{9}=$ & 7.40 & 1.08 & 6.30 & 1.11 & $9.50 \times 10^{9}$ & 1.00 \\
\hline 1012 & $9.80 \times 10^{9}$ & 7.80 & 5.50 & $9.30 \times 10^{3}$ & .4 .20 & 1.01 & 7.80 & $8.30 \times 10^{9}$ \\
\hline 1013 & 7.60 & 5.60 & 2.95 & 7.40 & 2.70 & $8.60 \times 109$ & 5.70 & 6.10 \\
\hline 1014 & 5.35 & 3.10 & $9.80 \times 10^{8}$ & 4.90 & 1.75 & 7.00 & 3.50 & 3.30 \\
\hline 1015 & 2.80 & $9.80 \times 10^{8}$ & 1.50 & 2.35 & $9.80 \times 10^{8}$ & 4.50 & 2.10 & 1.03 \\
\hline
\end{tabular}




\begin{tabular}{|l|l|l|l|l|l|l|l|l|}
1016 & $6.60 \times 108$ & 1.85 & $3.35 \times 107$ & $5.90 \times 108$ & 4.80 & 1.90 & 1.43 & $1.85 \times 108$ \\
1017 & $9.80 \times 107$ & $4.40 \times 107$ & & $9.20 \times 107$ & 1.85 & $4.30 \times 108$ & $9.40 \times 10^{8}$ & $4.40 \times 107$ \\
1018 & 3.10 & 2.25 & & 3.10 & $6.30 \times 10^{7}$ & $8.30 \times 10^{7}$ & 5.10 & 2.25 \\
1019 & 2.10 & $1.82 \times 1010$ & & 2.00 & 2.35 & 3.10 & 1.50 & \\
1020 & & 1.73 & & & & & $4.10 \times 10^{2}$ & \\
\hline
\end{tabular}

Table 15 Stress Relaxation Modulus of Specimen MM soaked in various Solvents

\begin{tabular}{|c|c|c|c|c|c|c|c|c|}
\hline Time(sec) & Air & Ace tone & Benzene & Xylene & $\begin{array}{l}\text { Chloro- } \\
\text { form }\end{array}$ & Eugenol & $\begin{array}{l}\text { Ethyl } \\
\text { alcohol }\end{array}$ & Water \\
\hline $10^{\circ}$ & $2.27 \times 1010$ & $1.89 \times 1010$ & $2.12 \times 1010$ & $2.28 \times 1010$ & $2.25 \times 1010$ & $2.28 \times 10^{10}$ & $2.35 \times 1010$ & $2.20 \times 1010$ \\
\hline 101 & 2.17 & 1.81 & 2.01 & 2.18 & 2.14 & 2.17 & 2.24 & 2.09 \\
\hline $10^{2}$ & 2.07 & 1.71 & 1.93 & 2.08 & 2.04 & 2.07 & 2.10 & 1.98 \\
\hline $10^{3}$ & 1.96 & 1.61 & 1.83 & 1.95 & 1.94 & 1.97 & 1.97 & 1.90 \\
\hline $10^{4}$ & 1.87 & 1.51 & 1.73 & 1.85 & 1.80 & 1.85 & 1.84 & 1.79 \\
\hline $10^{5}$ & 1.76 & 1.42 & 1.64 & 1.75 & 1.70 & 1.75 & 1.77 & 1.69 \\
\hline $10^{6}$ & 1.69 & 1.34 & 1.56 & 1.63 & 1.60 & 1.69 & 1.68 & 1.58 \\
\hline $10^{7}$ & 1.61 & 1.27 & 1.50 & 1.53 & 1.50 & 1.62 & 1.58 & 1.50 \\
\hline $10^{8}$ & 1.53 & 1.19 & 1.38 & 1.43 & 1.40 & 1.52 & 1.48 & 1.43 \\
\hline $10^{9}$ & 1.45 & 1.12 & 1.28 & 1.33 & 1.30 & 1.43 & 1.37 & 1.35 \\
\hline $10^{10}$ & 1.32 & 1.03 & 1.20 & 1.23 & 1.22 & 1.33 & 1.28 & 1.27 \\
\hline $10^{11}$ & 1.21 & $9.40 \times 109$ & 1.08 & 1.12 & 1.08 & 1.21 & 1.18 & 1.17 \\
\hline $10^{12}$ & 1.12 & 8.10 & $9.60 \times 10^{9}$ & 1.03 & $9.10 \times 109$ & 1.14 & 1.07 & 1.06 \\
\hline $10^{13}$ & $9.70 \times 109$ & 6.30 & 8.00 & $8.70 \times 109$ & 7.00 & 1.03 & $9.50 \times 109$ & $9.40 \times 109$ \\
\hline $10^{14}$ & 8.00 & 4.00 & 5.60 & 6.60 & 4.90 & $8.50 \times 109$ & 7.60 & 7.70 \\
\hline $10^{15}$ & 6.00 & 1.70 & 3.10 & 4.00 & 2.90 & 6.50 & 5.70 & 5.70 \\
\hline $10^{16}$ & 3.50 & $3.60 \times 108$ & 1.05 & 1.60 & 1.36 & 4.00 & 3.80 & 3. 30 \\
\hline $10^{17}$ & 1.33 & $7.10 \times 107$ & $1.60 \times 10^{8}$ & $3.30 \times 108$ & $3.90 \times 103$ & 1.65 & 2.17 & 1.35 \\
\hline $10^{18}$ & $1.55 \times 10^{8}$ & 3.45 & $4.30 \times 107$ & $5.00 \times 107$ & $8.70 \times 107$ & $2.45 \times 108$ & 1.05 & $3.00 \times 108$ \\
\hline $10^{19}$ & $5.80 \times 10^{7}$ & & 2.65 & 3.00 & 2.75 & $4.20 \times 107$ & $3.50 \times 10^{8}$ & $5.50 \times 109$ \\
\hline $10^{20}$ & 3.10 & & & & 1.50 & 2.25 & $7.10 \times 107$ & 2.35 \\
\hline $10^{21}$ & 2.63 & & & & & & & \\
\hline
\end{tabular}


矢鳴 律生

Table 16 Relaxation Time Spectrum of Specimen PP soaked in various Solvents

\begin{tabular}{|c|c|c|c|c|c|c|c|c|}
\hline \begin{tabular}{|l|} 
Time $(\sec )$ \\
\end{tabular} & Air & Acetone & Benzene & Xylene & $\begin{array}{l}\text { Chloro- } \\
\text { form }\end{array}$ & Eugenol & $\begin{array}{l}\text { Ethyl } \\
\text { alcohol }\end{array}$ & Water \\
\hline $10^{3}$ & $4.32 \times 10^{8}$ & $3.37 \times 10^{3}$ & $3.45 \times 10^{3}$ & $2.77 \times 10^{8}$ & $4.52 \times 10^{3}$ & $3.71 \times 10^{9}$ & $2.04 \times 10^{8}$ & $3.78 \times 10^{3}$ \\
\hline 102 & 4.33 & 3.57 & 4.15 & 4.46 & 4.63 & 4.26 & 3.64 & 4.02 \\
\hline 104 & 4.26 & 4.60 & 4.01 & 4.82 & 5.24 & 4.34 & 3.61 & 5.22 \\
\hline 105 & 3.87 & 4.37 & 4.61 & 5.54 & 7.60 & 4.58 & 4.19 & 4.64 \\
\hline 103 & 5.79 & 6.78 & 6.01 & 7.15 & $1.15 \times 10^{9}$ & 6.80 & 4.69 & 6.13 \\
\hline 1010 & $1.05 \times 10^{9}$ & $1.18 \times 10^{3}$ & $1.02 \times 10^{3}$ & $1.20 \times 10^{3}$ & $4.65 \times 10^{3}$ & $1.12 \times 10^{3}$ & 6.70 & $1.12 \times 10^{9}$ \\
\hline 1011 & 1.06 & $8.80 \times 10^{?}$ & 1.19 & 1.06 & 2.63 & 1.04 & 7.38 & $9.46 \times 10^{9}$ \\
\hline $10: 2$ & $7.71 \times 10^{3}$ & 4.91 & $1.29 \times 103$ & $6.58 \times 103$ & 1.29 & $5.84 \times 10^{3}$ & 7.54 & 5.02 \\
\hline 1013 & 3.46 & 2.38 & 2.86 & 3.47 & $5.82 \times 107$ & 2.36 & 7.04 & 2.22 \\
\hline 1014 & 1.10 & 1.17 & 1.06 & 1.22 & $3.02 \times 10^{3}$ & 1.03 & 5.68 & 1.16 \\
\hline 1015 & $4.99 \times 10^{7}$ & $5.55 \times 10^{7}$ & $3.30 \times 107$ & $3.69 \times 107$ & 2.60 & $4.59 \times 10^{7}$ & 4.55 & $4.02 \times 10^{7}$ \\
\hline 1016 & 2.08 & 2.44 & 1.32 & 1.20 & & 1.91 & 3.26 & 1.15 \\
\hline 1017 & $8.28 \times 10^{5}$ & 1.09 & $5.63 \times 10^{5}$ & 4.92 & & $8.34 \times 105$ & 2.20 & $3.37 \times 10^{5}$ \\
\hline 1018 & 3.54 & & & & & & 1.39 & \\
\hline 1019 & & & & & & & $2.14 \times 10^{7}$ & \\
\hline 1030 & & & & & & & $8.39 \times 10^{3}$ & \\
\hline
\end{tabular}

Table 17 Relaxation Time Spectrum of Specimen MP soaked in various Solvents

\begin{tabular}{|c|l|l|l|l|l|l|l|l|}
\hline Time(sec) & Air & Acetone & Benzene & Xylene & $\begin{array}{l}\text { Chloro- } \\
\text { form }\end{array}$ & Eugenol & $\begin{array}{l}\text { Ethyl } \\
\text { alcohol }\end{array}$ & Water \\
\hline 103 & $2.94 \times 10^{3}$ & $4.14 \times 10^{3}$ & $2.82 \times 108$ & $3.33 \times 10^{3}$ & $4.02 \times 108$ & $4.34 \times 10^{3}$ & $4.41 \times 10^{3}$ & $4.05 \times 10^{3}$ \\
$10^{2}$ & 3.80 & 4.37 & 3.84 & 4.34 & 4.41 & 4.45 & 4.41 & 4.57 \\
107 & 3.96 & 4.53 & 3.57 & 4.22 & 4.17 & 4.32 & 4.48 & 4.33 \\
$10^{3}$ & 4.07 & 4.30 & 3.77 & 4.35 & 4.36 & 4.18 & 4.38 & 4.44 \\
103 & 4.76 & 4.55 & 5.09 & 4.56 & 4.95 & 4.47 & 4.81 & 4.15 \\
1010 & 4.92 & 4.25 & 6.84 & 6.05 & 7.83 & 4.95 & 5.92 & 5.31 \\
1011 & 5.18 & 6.07 & 9.33 & 7.06 & 8.24 & 5.14 & 7.47 & 7.46 \\
1012 & $1.00 \times 10^{3}$ & 8.32 & 9.43 & 8.10 & 7.01 & 6.23 & 8.37 & 9.47 \\
1013 & $9.42 \times 10^{3}$ & $1.00 \times 10^{3}$ & 9.95 & $1.04 \times 10^{9}$ & 5.74 & 7.81 & 9.44 & $1.13 \times 109$ \\
1014 & $1.08 \times 10^{3}$ & 1.07 & 7.66 & 1.11 & 4.05 & 9.31 & 8.04 & 1.06 \\
1015 & 1.02 & $5.76 \times 10^{30}$ & 1.23 & 1.01 & 2.73 & $1.03 \times 10^{3}$ & 4.24 & $7.35 \times 103$ \\
\hline
\end{tabular}




\begin{tabular}{l|l|l|l|l|l|l|l|l|}
1016 & $5.88 \times 10^{3}$ & 1.54 & $1.13 \times 10^{7}$ & $5.04 \times 10^{3}$ & 1.63 & $9.38 \times 10^{3}$ & 2.42 & 1.54 \\
107 & $7.62 \times 10^{7}$ & $1.82 \times 1.07$ & & $6.35 \times 10^{7}$ & $8.20 \times 10^{7}$ & 3.58 & 2.06 & $2.04 \times 10^{7}$ \\
1018 & $7.70 \times 10^{5}$ & $4.46 \times 10^{3}$ & & $8.57 \times 10^{5}$ & 3.19 & $4.42 \times 10^{7}$ & 1.82 & $4.45 \times 10^{3}$ \\
1019 & 2.53 & & & 2.92 & $7.62 \times 10^{5}$ & $7.51 \times 105$ & 1.02 & \\
1030 & & & & & & 3.11 & $1.33 \times 10^{2}$ & \\
\hline
\end{tabular}

Table 18 Relaxation Time Spectrum of Speeimcn MM soaked in various Solvents

\begin{tabular}{|c|c|c|c|c|c|c|c|c|}
\hline $\mid \begin{array}{r}\text { Solvent } \\
\text { Time(sec) }\end{array}$ & Air & Acetone & Benzene & Xylene & $\begin{array}{l}\text { Chloro- } \\
\text { form }\end{array}$ & Eugenol & $\begin{array}{l}\text { Ethyl } \\
\text { alcohol }\end{array}$ & Water \\
\hline 103 & $2.89 \times 10^{3}$ & $2.84 \times 10^{3}$ & $3.92 \times 10^{3}$ & $3.50 \times 10^{3}$ & $3.84 \times 10^{3}$ & $3.28 \times 10^{9}$ & $4.72 \times 10^{8}$ & $5.17 \times 10^{3}$ \\
\hline 102 & 3.69 & 5.06 & 3.98 & 4.95 & 4.14 & 4.51 & 5.37 & 4.10 \\
\hline 104 & 3.70 & 3.95 & 3.97 & 4.44 & 4.65 & 4.23 & 4.56 & 3.93 \\
\hline 103 & 1.49 & 3.40 & 3.80 & 4.08 & 4.46 & 3.77 & 3.94 & 3.85 \\
\hline 103 & 4.25 & 3.59 & 3.39 & 4.68 & 4.42 & 4.43 & 4.43 & 3.80 \\
\hline 1010 & 5.13 & 3.99 & 5.12 & 4.66 & 6.11 & 4.37 & 4.58 & 3.84 \\
\hline 1011 & 5.39 & 5.27 & 5.64 & 5.11 & 7.05 & 4.24 & 4.97 & 4.36 \\
\hline 1012 & 5.97 & 7.10 & 7.33 & 6.23 & 8.44 & 4.66 & 5.99 & 5.06 \\
\hline 1013 & 7.53 & 9.14 & 9.33 & 8.24 & 8.99 & 6.68 & 7.20 & 6.84 \\
\hline 1014 & 8.93 & $1.00 \times 103$ & $1.07 \times 10^{3}$ & 9.84 & 9.06 & 8.26 & 8.50 & 8.69 \\
\hline 1015 & 9.64 & $8.38 \times 103$ & 1.03 & $1.16 \times 10^{9}$ & 7.99 & 9.87 & 8.55 & 9.96 \\
\hline 1016 & 9.94 & 2.78 & $6.88 \times 103$ & $9.07 \times 10^{3}$ & 6.11 & $1.12 \times 10^{9}$ & 9.46 & 9.17 \\
\hline 1017 & 6.64 & $3.56 \times 10^{7}$ & 1.37 & 2.68 & 2.48 & $9.19 \times 10^{3}$ & 5.99 & 6.54 \\
\hline $10 ! 8$ & 2.20 & $6.78 \times 10^{3}$ & $1.43 \times 107$ & 2.12 & $5.44 \times 10^{7}$ & 2.61 & 4.47 & 2.53 \\
\hline 1019 & $2.35 \times 10^{7}$ & & & 6.51 & 1.02 & I. $72 \times 107$ & 1.91 & $3.29 \times 10^{5}$ \\
\hline 1030 & $4.75 \times 105$ & & & & $3.09 \times 10^{5}$ & $4.44 \times 103$ & $4.42 \times 10^{\prime}$ & $5.44 \times 10^{6}$ \\
\hline 1031 & & & & & & & $6.54 \times 10^{3}$ & 2.02 \\
\hline
\end{tabular}

Table 19 Temperature Dependence of $\left\{\frac{\mathrm{d}\left(\log a_{\mathrm{T}}\right)}{\mathrm{d} T}\right\}$ of unsoaked Specimen

\begin{tabular}{|c|c|c|c|c|c|}
\hline \multicolumn{2}{|c|}{ PP-O } & \multicolumn{2}{c|}{ MP-O } & \multicolumn{2}{c|}{ MM-O } \\
\hline Temp $\left({ }^{\circ} \mathrm{C}\right)$ & $\frac{\operatorname{d}\left(\log a_{\mathrm{T}}\right)}{\mathrm{dT}}$ & $\operatorname{Temp}\left({ }^{\circ} \mathrm{C}\right)$ & $\frac{\mathrm{d}\left(\log a_{\mathrm{T}}\right)}{\mathrm{dT}}$ & $\mathrm{Temp}\left({ }^{\circ} \mathrm{C}\right)$ & $\frac{\mathrm{d}\left(\log a_{\mathrm{T}}\right)}{\mathrm{dT}}$ \\
\hline 40.0 & 0.140 & 40.0 & 0.167 & 40.0 & 0.156 \\
50.0 & 0.195 & 60.0 & 0.167 & 50.0 & 0.177 \\
\hline
\end{tabular}




\begin{tabular}{|r|r|r|r|r|r|}
60.0 & 0.238 & 80.0 & 0.167 & 60.0 & 0.183 \\
70.0 & 0.246 & 90.0 & 0.193 & 80.0 & 0.194 \\
80.0 & 0.248 & 100.0 & 0.236 & 100.0 & 0.233 \\
85.0 & 0.275 & 105.0 & 0.267 & 110.1 & 0.288 \\
90.0 & 0.280 & 110.0 & 0.200 & 115.0 & 0.333 \\
100.0 & 0.220 & 120.0 & 0.163 & 120.0 & 0.240 \\
110.0 & 0.190 & 130.0 & 0.111 & 130.0 & 0.160 \\
\hline
\end{tabular}

Table 20 Temperature Dependence of $\left\{\frac{\mathrm{d}\left(\log a_{\mathrm{T}}\right)}{\mathrm{dT}}\right\}$ of Specimen soaked in Acetone

\begin{tabular}{|c|c|c|c|c|c|}
\hline \multicolumn{2}{|c|}{ PP-A } & \multicolumn{2}{|c|}{ MP-A } & \multicolumn{2}{|c|}{ MM-A } \\
\hline Temp ( $\left.{ }^{\circ} \mathrm{C}\right)$ & $\frac{\mathrm{d}\left(\log a_{\mathrm{T}}\right)}{\mathrm{dT}}$ & $\mathrm{Temp}\left({ }^{\circ} \mathrm{C}\right)$ & $\frac{\mathrm{d}\left(\log a_{\mathrm{T}}\right)}{\mathrm{dT}}$ & $\mathrm{Temp}\left({ }^{\circ} \mathrm{C}\right)$ & $\frac{\mathrm{d}\left(\log a_{\mathrm{T}}\right)}{\mathrm{dT}}$ \\
\hline 40.0 & 0.156 & 40.0 & 0.169 & 40.0 & 0.158 \\
60.0 & 0.169 & 60.0 & 0.169 & 60.0 & 0.158 \\
80.0 & 0.233 & 80.0 & 0.180 & 80.0 & 0.175 \\
90.0 & 0.331 & 100.0 & 0.257 & 100.0 & 0.240 \\
100.0 & 0.265 & 104.0 & 0.317 & 110.0 & 0.297 \\
110.0 & 0.225 & 110.0 & 0.278 & 120.0 & 0.209 \\
& & 120.0 & 0.121 & & \\
\hline
\end{tabular}

Table 21 Temperature Dependence of $\left\{\frac{\mathrm{d}\left(\log a_{\mathrm{T}}\right)}{\mathrm{dT}}\right\}$ of Specimen soaked in Benzene

\begin{tabular}{|c|c|c|c|c|c|}
\hline \multicolumn{2}{|c|}{ PP-B } & \multicolumn{2}{c|}{ PP-B } & \multicolumn{2}{c|}{ MM-B } \\
\hline Temp $\left({ }^{\circ} \mathrm{C}\right)$ & $\frac{\mathrm{d}\left(\log a_{\mathrm{T}}\right)}{\mathrm{dT}}$ & $\mathrm{Temp}\left({ }^{\circ} \mathrm{C}\right)$ & $\frac{\mathrm{d}\left(\log a_{\mathrm{T}}\right)}{\mathrm{dT}}$ & $\mathrm{Temp}\left({ }^{\circ} \mathrm{C}\right)$ & $\frac{\mathrm{d}\left(\log a_{\mathrm{T}}\right)}{\mathrm{dT}}$ \\
\hline 40.0 & 0.154 & 40.0 & 0.136 & 60.0 & 0.170 \\
60.0 & 0.228 & 60.0 & 0.154 & 80.0 & 0.172 \\
80.0 & 0.300 & 80.0 & 0.176 & 100.0 & 0.199 \\
86.0 & 0.300 & 100.0 & 0.275 & 110.0 & 0.300 \\
90.0 & 0.237 & 103.5 & 0.368 & 120.0 & 0.188 \\
100.0 & 0.154 & 110.0 & 0.250 & & \\
110.0 & 0.120 & 120.0 & 0.132 & & \\
\hline
\end{tabular}


Table 22 Temperature Dependence of $\left\{\frac{\mathrm{d}\left(\log a_{\mathrm{T}}\right)}{\mathrm{dT}}\right\}$ of Specimen soaked in Xylene

\begin{tabular}{|c|c|c|c|c|c|}
\hline \multicolumn{2}{|c|}{ PP-X } & \multicolumn{2}{|c|}{ MP -X } & \multicolumn{2}{c|}{ MM-X } \\
\hline Temp ( $\left.{ }^{\circ} \mathrm{C}\right)$ & $\frac{\mathrm{d}\left(\log a_{\mathrm{T}}\right)}{\mathrm{dT}}$ & $\mathrm{Temp}\left({ }^{\circ} \mathrm{C}\right)$ & $\frac{\mathrm{d}\left(\log a_{\mathrm{T}}\right)}{\mathrm{dT}}$ & $\mathrm{Temp}\left({ }^{\circ} \mathrm{C}\right)$ & $\frac{\mathrm{d}\left(\log a_{\mathrm{T}}\right)}{\mathrm{dT}}$ \\
\hline 40.0 & 0.171 & 50.0 & 0.155 & 50.0 & 0.162 \\
60.0 & 0.230 & 70.0 & 0.170 & 70.0 & 0.160 \\
70.0 & 0.259 & 90.0 & 0.203 & 90.0 & 0.177 \\
85.0 & 0.278 & 100.0 & 0.275 & 100.0 & 0.204 \\
100.0 & 0.183 & 104.0 & 0.331 & 110.5 & 0.337 \\
110.0 & 0.132 & 110.0 & 0.265 & 115.0 & 0.300 \\
& & 120.0 & 0.141 & 120.0 & 0.182 \\
\hline
\end{tabular}

Table 23 Temperature Dependence of $\left\{\frac{\mathrm{d}\left(\log a_{\mathrm{T}}\right)}{\mathrm{dT}}\right\}$ of Specimen soaked in Chloroform

\begin{tabular}{|c|c|c|c|c|c|}
\hline \multicolumn{2}{|c|}{ PP $-\mathrm{C}$} & \multicolumn{2}{|c|}{ MP-C } & \multicolumn{2}{c|}{ MM-C } \\
\cline { 2 - 5 } Temp $\left({ }^{\circ} \mathrm{C}\right)$ & $\frac{\mathrm{d}\left(\log a_{\mathrm{T}}\right)}{\mathrm{dT}}$ & Temp $\left({ }^{\circ} \mathrm{C}\right)$ & $\frac{\mathrm{d}\left(\log a_{\mathrm{T}}\right)}{\mathrm{dT}}$ & $\mathrm{Temp}\left({ }^{\circ} \mathrm{C}\right)$ & $\frac{\mathrm{d}\left(\log a_{\mathrm{T}}\right)}{\mathrm{dT}}$ \\
\hline 40.0 & 0.193 & 40.0 & 0.168 & 40.0 & 0.117 \\
60.0 & 0.226 & 60.0 & 0.174 & 60.0 & 0.175 \\
85.0 & 0.264 & 80.0 & 0.220 & 80.0 & 0.206 \\
90.0 & 0.200 & 104.0 & 0.433 & 100.0 & 0.243 \\
100.0 & 0.173 & 110.0 & 0.241 & 109.0 & 0.365 \\
110.0 & 0.140 & 120.0 & 0.140 & 120.0 & 0.190 \\
\hline
\end{tabular}

Table 24 Temperature Dependence of $\left\{\frac{\mathrm{d}\left(\log a_{\mathrm{T}}\right)}{\mathrm{dT}}\right\}$ of Specimen soaked in Eugenol

\begin{tabular}{|c|r|r|r|r|r|}
\hline \multicolumn{2}{|c|}{ PP-Eu } & \multicolumn{2}{|c|}{ MP-Eu } & \multicolumn{2}{c|}{ MM-Eu } \\
\hline Temp $\left({ }^{\circ} \mathrm{C}\right)$ & $\frac{\mathrm{d}\left(\log a_{\mathrm{T}}\right)}{\mathrm{dT}}$ & $\operatorname{Temp}\left({ }^{\circ} \mathrm{C}\right)$ & $\frac{\mathrm{d}\left(\log a_{\mathrm{T}}\right)}{\mathrm{dT}}$ & $\operatorname{Temp}\left({ }^{\circ} \mathrm{C}\right)$ & $\frac{\mathrm{d}\left(\log a_{\mathrm{T}}\right)}{\mathrm{dT}}$ \\
\hline 40.0 & 0.185 & 40.0 & 0.158 & 70.0 & 0.194 \\
60.0 & 0.206 & 60.0 & 0.187 & 100.0 & 0.209 \\
\hline
\end{tabular}


矢鳴 ‘律生

\begin{tabular}{|r|r|r|r|r|l|}
\hline 80.0 & 0.269 & 80.0 & 0.218 & 110.0 & 0.208 \\
90.0 & 0.312 & 100.0 & 0.282 & 115.0 & 0.314 \\
100.0 & 0.197 & 104.0 & 0.378 & 120.0 & 0.205 \\
110.0 & 0.125 & 110.0 & 0.320 & \\
& & 120.0 & 0.159 & \\
\hline
\end{tabular}

Table 25 Temperature Dependence of $\left\{\frac{\mathrm{d}\left(\log a_{\mathrm{T}}\right)}{\mathrm{dn}}\right\}$ of Specimen soaked in Ethyl Alcohol

\begin{tabular}{|c|c|c|c|c|c|}
\hline \multicolumn{2}{|c|}{ PP-Et } & \multicolumn{2}{|c|}{ MP-Et } & \multicolumn{2}{c|}{ MM-Et } \\
\hline Temp $\left({ }^{\circ} \mathrm{C}\right)$ & $\frac{\mathrm{d}\left(\log a_{\mathrm{T}}\right)}{\mathrm{dT}}$ & $\mathrm{Temp}\left({ }^{\circ} \mathrm{C}\right)$ & $\frac{\mathrm{d}\left(\log a_{\mathrm{T}}\right)}{\mathrm{dT}}$ & $\mathrm{Temp}\left({ }^{\circ} \mathrm{C}\right)$ & $\frac{\mathrm{d}\left(\log a_{\mathrm{T}}\right)}{\mathrm{dT}}$ \\
\hline 40.0 & 0.147 & 40.0 & 0.145 & 40.0 & 0.157 \\
60.0 & 0.163 & 60.0 & 0.162 & 60.0 & 0.178 \\
80.0 & 0.238 & 80.0 & 0.200 & 80.0 & 0.231 \\
100.0 & 0.317 & 100.0 & 0.316 & 100.0 & 0.268 \\
105.0 & 0.188 & 110.0 & 0.243 & 116.0 & 0.332 \\
110.0 & 0.255 & 116.0 & 0.603 & 120.0 & 0.294 \\
115.0 & 0.338 & 120.0 & 0.259 & & \\
120.0 & 0.320 & 130.0 & 0.108 & & \\
\hline
\end{tabular}

Table 26 Temperature Dependence of $\left\{\frac{\mathrm{d}\left(\log a_{\mathrm{T}}\right)}{\mathrm{dT}}\right\}$ of Specimen soaked in Water

\begin{tabular}{|c|c|c|c|c|c|}
\hline \multicolumn{2}{|c|}{$P P-W$} & \multicolumn{2}{|c|}{$\mathrm{MP}-\mathrm{W}$} & \multicolumn{2}{|c|}{$M M-W$} \\
\hline $\operatorname{Temp}\left({ }^{\circ} \mathrm{C}\right)$ & $-\frac{\mathrm{d}\left(\log a_{\mathrm{T}}\right)}{\mathrm{dT}}$ & $\operatorname{Temp}\left({ }^{\circ} \mathrm{C}\right)$ & $\frac{\mathrm{d}\left(\log a_{\mathrm{T}}\right)}{\mathrm{dT}}$ & $\operatorname{Temp}\left({ }^{\circ} \mathrm{C}\right)$ & $\frac{\mathrm{d}\left(\log a_{\mathrm{T}}\right)}{\mathrm{dT}}$ \\
\hline 40.0 & 0.156 & 40.0 & 0.149 & 40.0 & 0.142 \\
\hline 60.0 & 0.190 & 60.0 & 0.163 & 60.0 & 0.170 \\
\hline 80.0 & 0.257 & 80.0 & 0.182 & 80.0 & 0.183 \\
\hline 89.0 & 0.282 & 100.0 & 0.328 & 100.0 & 0.241 \\
\hline 100.0 & 0.221 & 104.0 & 0.477 & 110.0 & 0.366 \\
\hline & & 110.0 & 0.242 & 114.0 & 0.450 \\
\hline & & 120.0 & 0.137 & 120.0 & 0.165 \\
\hline
\end{tabular}


Table 27 Temperature Dependence of Apparent Activation Energy on Stress Relaxation of Specimens

\begin{tabular}{|c|c|c|c|c|c|c|}
\hline & \multicolumn{2}{|c|}{ PP } & \multicolumn{2}{|c|}{ MP } & \multicolumn{2}{|c|}{ MM } \\
\hline & $\operatorname{Temp}\left({ }^{\circ} \mathrm{C}\right)$ & $\Delta \mathrm{H}(\mathrm{kcal} / \mathrm{mol})$ & $\operatorname{Temp}\left({ }^{\circ} \mathrm{C}\right)$ & $\Delta \mathrm{H}(\mathrm{kcal} / \mathrm{mol})$ & $\operatorname{Temp}\left({ }^{\circ} \mathrm{C}\right)$ & $\Delta \mathrm{H}(\mathrm{kcal} / \mathrm{mol})$ \\
\hline \multirow{4}{*}{ Unsoaked } & 90.0 & 204 & 105.0 & 221 & 115.5 & 234 \\
\hline & 95.0 & 179 & 110.0 & 189 & 120.5 & 204 \\
\hline & 105.0 & 133 & 114.0 & 168 & 125.5 & 172 \\
\hline & 110.0 & 118 & 120.0 & 143 & & \\
\hline \multirow{4}{*}{ Acetone } & 90.0 & 204 & 104.0 & 220 & 110.0 & 227 \\
\hline & 95.0 & 174 & 110.5 & 180 & 115.0 & 194 \\
\hline & 100.0 & 151 & 115.0 & 158 & 120.0 & 168 \\
\hline & 105.0 & 133 & 119.0 & 148 & 125.0 & 147 \\
\hline \multirow{4}{*}{ Benzene } & 86.0 & 199 & 103.5 & 219 & 110.0 & 227 \\
\hline & 95.0 & 152 & 107.8 & 191 & 116.0 & 188 \\
\hline & 101.0 & 130 & 111.0 & 174 & 120.0 & 168 \\
\hline & & & 115.0 & 156 & 125.0 & 147 \\
\hline \multirow{4}{*}{ Xylene } & 85.0 & 198 & 104.0 & 220 & 110.5 & 228 \\
\hline & 90.0 & 169 & 110.0 & 182 & 116.0 & 191 \\
\hline & 100.0 & 129 & 115.0 & 158 & 121.0 & 166 \\
\hline & 105.0 & 115 & 121.0 & 136 & 125.0 & 149 \\
\hline \multirow{4}{*}{ Chloroform } & 85.0 & 198 & 104.0 & 220 & 109.0 & 226 \\
\hline & 89.5 & 172 & 110.0 & 182 & 115.0 & 187 \\
\hline & 94.5 & 149 & 115.0 & 158 & 120.0 & 162 \\
\hline & 100.0 & 129 & 120.0 & 139 & 125.0 & 143 \\
\hline \multirow{4}{*}{ Eugenol } & 90.0 & 204 & 104.0 & 220 & 115.0 & 233 \\
\hline & 95.0 & 174 & 110.0 & 182 & 120.0 & 199 \\
\hline & 100.0 & 151 & 116.0 & 156 & 125.0 & 172 \\
\hline & 105.0 & 133 & 121.0 & 138 & & \\
\hline \multirow{4}{*}{ Ethyl alcohl } & 100.0 & 215 & 105.1 & 221 & 116.0 & 234 \\
\hline & 104.5 & 187 & 109.8 & 190 & 120.5 & 203 \\
\hline & 110.0 & 159 & 113.0 & 173 & 126.0 & 173 \\
\hline & 115.5 & 138 & 116.2 & 159 & & \\
\hline \multirow{4}{*}{ Water } & 89.0 & 203 & 104.0 & 220 & 114.0 & 232 \\
\hline & 95.0 & 168 & 110.5 & 180 & 118.0 & 204 \\
\hline & 100.0 & 146 & 115.0 & 158 & 125.0 & 167 \\
\hline & 105.5 & 127 & 119.0 & 143 & & \\
\hline
\end{tabular}

